\section{Pacific Northwest}

National Laboratory

Operated by Battelle for the

U.S. Department of Energy

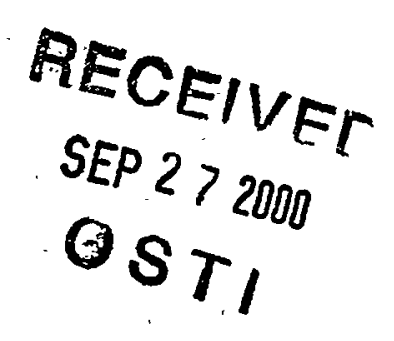

J. Abrefah

D. L. Alexander

S. C. Marschman

September 2000

Prepared for the U.S. Department of Energy under Contract DE-AC06-76RL01830 


\section{DISCLAIMER}

Portions of this document may be illegible in electronic image products. Images are produced from the best available original document. 


\title{
Drying Results of K-Basin Damaged/Corroded SNF Internal Sludge and Surface Coating
}

\author{
J. Abrefah \\ D. L. Alexander \\ S. C. Marschman
}

September 2000

Prepared for

the U.S. Department of Energy

under Contract DE-AC06-76RL01830

Pacific Northwest National Laboratory

Richland, Washington 99352 


\section{Summary}

Experiments were performed using a thermogravimetric analysis (TGA) system by Pacific Northwest National Laboratory (PNNL) to study the drying behavior of the K-Basin spent nuclear fuel (SNF) internal sludge and two different surface coatings of SNF elements. These measurements were conducted in support of the safety and process analyses of the proposed Integrated Process Strategy (IPS) to move the N-Reactor fuel stored at K-Basin to an interim storage facility. These limited experiments on the corrosion products of K-Basin SNF material were part of the broad studies performed to ascertain the bounding pressurization of the Multi-Canister Overpack (MCO).

Seven SNF internal sludge samples taken from different damage regions of three damaged/corroded outer K-Basin SNF elements were dried. Additionally, two surface coating samples taken from two SNF elements stored at $\mathrm{K}$-West were tested. All the tests were performed in a vacuum atmosphere with the same temperature ramp rate of about $0.4^{\circ} \mathrm{C} / \mathrm{min}$. Each TGA test sample was weighed before and after the test on a balance located in the Shielded Analytical Laboratory hot cell. The test samples were vacuum dried in the TGA system for about 24 hours prior to heating them at the rate of $0.4^{\circ} \mathrm{C} / \mathrm{min}$. The observations from the weight change data are summarized below.

A fraction of the SNF internal sludge was reactive and was readily oxidized by the background gas in a vacuum of about $10^{-3}$ torr. The oxidation reaction occurred within the entire test temperature range of about 30 to $550^{\circ} \mathrm{C}$. The weight gain associated with the oxidation reaction made it very difficult to accurately ascertain the thermal dissociation of the hydrated fraction (i.e., the weight loss) of the internal sludge samples. Nonetheless, during the runs, the samples at certain period(s) showed weight losses which were attributed to thermal decomposition of the hydrated fraction of the sludge. The dehydration of the sludge by thermal decomposition for most of the runs occurred at temperatures below $500^{\circ} \mathrm{C}$ and started at about $200^{\circ} \mathrm{C}$. The major portion of the observed weight loss for the internal sludge occurred between the temperature range of about $200^{\circ} \mathrm{C}$ to $400^{\circ} \mathrm{C}$. The study of drying of $105-\mathrm{K}$-East canister sludge by Abrefah et al. ${ }^{1}$ also showed a major dehydration peak at about the same temperature range, suggesting that the hydrated phase of the internal sludge may be the same as that of the canister sludge. This inference from the weight measurements is supported by an $\mathrm{x}$-ray diffraction (XRD) analysis that identified the uranium trioxide hydrate as a component of the internal sludge. However, the fraction of the internal sludge that was hydrated may have been small compared to the canister sludge.

The coating sample cs 4 yielded the highest moisture content of all the corrosion products tested. This coating lost about 26 weight percent of its initial weight for the two samples tested. The decomposition characteristics and the color of the dried sample suggest that the initial material may be aluminum hydroxide, $\mathrm{Al}(\mathrm{OH})_{3}$. The thermal decomposition of this coating started at temperatures slightly above $100^{\circ} \mathrm{C}$ and showed two decomposition peaks at temperatures of about $117^{\circ} \mathrm{C}$ and $274^{\circ} \mathrm{C}$. And, the decomposition reaction was essentially complete at a temperature of $400^{\circ} \mathrm{C}$, which agrees with the

\footnotetext{
${ }^{1}$ Abrefah, J., H. C. Buchanan, and S. C. Marschman. 1998. Drying Behavior of K-East Canister Sludge. PNNL-11628, Pacific Northwest National Laboratory, Richland, Washington.
} 
literature data on vacuum drying of aluminum hydroxides. ${ }^{1}$ The measured weight loss of 26 weight percent is less than the theoretical water content of $\mathrm{Al}(\mathrm{OH})_{3}\left(\mathrm{i} . \mathrm{e} . \mathrm{Al}_{2} \mathrm{O}_{3} \cdot 3 \mathrm{H}_{2} \mathrm{O}\right.$ ) which is 35 weight percent and the difference may be due to the following:

- impurities in the coating sample

- non-stoichiometric coating sample due to loss of some water molecules during the prior sample drying at ambient conditions

- system measurement accuracy including sample loss during transfer.

The reddish brown coating sample, cs7, had more moisture content (i.e., weight percent) than the internal sludge samples but less than the aluminum hydroxide sample (cs4). Hydrated iron oxide has been identified as the main chemical phase for the cs7 coating sample by an XRD analysis. The decomposition reaction of this coating started below $100^{\circ} \mathrm{C}$ and the weight loss process continued throughout the temperature range of the run. The characteristics of the observed weight loss curves for the two runs were very similar for most of the temperature range except that the duplicate run showed a significant weight loss at a temperature of about $500^{\circ} \mathrm{C}$. Additionally, the total weight loss by the duplicate run (i.e., 10 weight percent) is higher than that of the first run (i.e., 3 weight percent). The observed differences in weight loss by the two runs may be due to samples with different initial hydrated fractions.

${ }^{1}$ Newsome, J. W., H. W. Heiser, A. S. Russell, and H. C. Stumpf. 1960. Aluminum Properties. Technical Paper No. 10, 2nd Rev., Aluminum Company of America, Pittsburgh, Pennsylvania. 


\section{Acknowledgments}

The campaign to ship SNF samples from the K-Basins to Pacific Northwest National Laboratory for characterization activities including the drying tests was made possible through the dedicated efforts of the operations staff at the K-Basins and the DESH SNF characterization group under the management of Ronald P. Omberg and his associates, Bruce Makenas, David Bergmann, and Leo Lawrence. The authors also extend our appreciation and thanks to all the hot cell technicians of Postirradiation Testing Laboratory (PTL) and the Radiochemistry Processing Laboratory (RPL) Shielded Analytical Laboratory (SAL), who were involved in preparation of the TGA test samples. 


\section{Quality Assurance}

This work was conducted under the Quality Assurance Program; Pacific Northwest National Laboratory (PNNL) SNF-70-001, SNF Quality Assurance Program, as implemented by the PNNL SNF Characterization Project Operations Manual. This QA program has been evaluated and determined to effectively implement the requirements of DOE/RW-0333P, Quality Assurance Requirements and Description (QARD). Compliance with the QARD is mandatory for projects that generate data used to support the development of a permanent High-Level Nuclear Waste repository. Further, the U.S. Department of Energy has determined that the testing activities which generated the results documented in this report shall comply with the QARD.

Supporting records for this test are located in the permanent PNNL SNF Characterization Project records, "Drying Results of K-Basin Damaged/Corroded SNF Internal Sludge and Surface Coating." 


\section{Acronyms}

DOE U.S. Department of Energy

DESH Duke Engineering \& Services, Hanford

DSC Differential Scanning Calorimeter

ID Identification

IPS Integrated Process Strategy

KE 105-K-East

KW 105-K West

MCO Multi-Canister Overpack

MS mass spectrometer

PNNL Pacific Northwest National Laboratory

PTL Postirradiation Testing Laboratory

QA Quality Assurance

QARD Quality Assurance Requirements and Description

QMS quadrupole mass spectrometer

SAL Shielded Analytical Laboratory

SNF spent nuclear fuel

TGA thermogravimetric analysis

XRD $\quad$-ray diffraction 



\section{Contents}

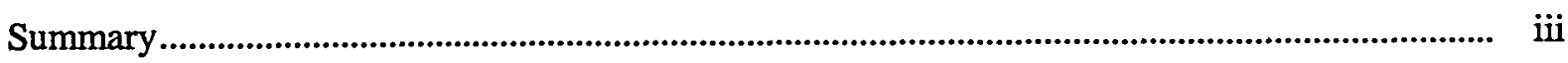

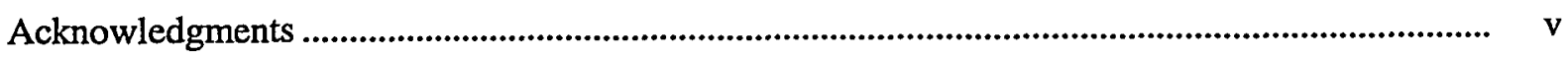

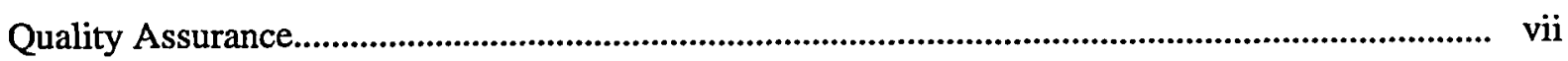

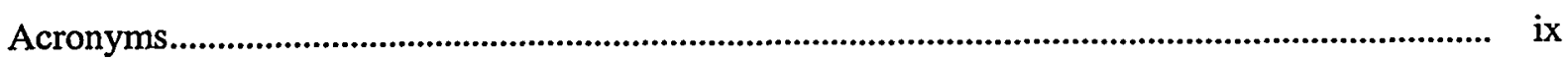

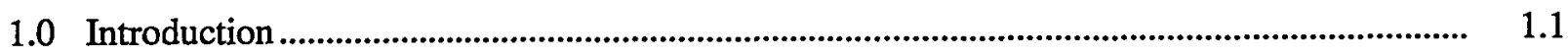

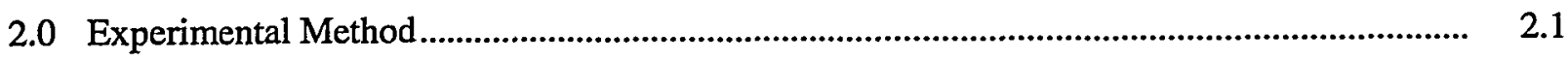

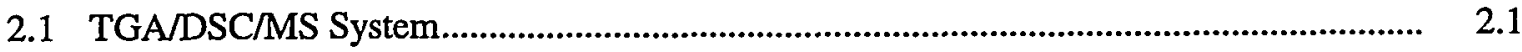

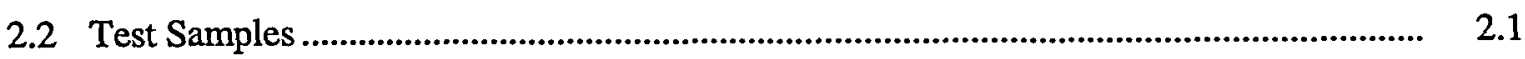

2.2.1 SNF Internal Sludge Samples ........................................................................ 2.1

2.2.2 SNF Element Surface Coatings................................................................... 2.3

2.2.3 Sample Preparation and Testing ................................................................... 2.3

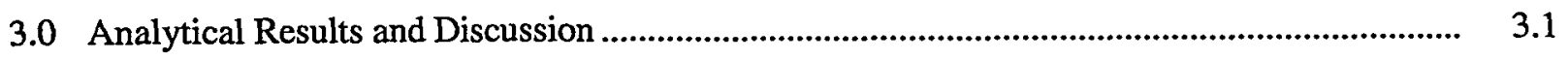

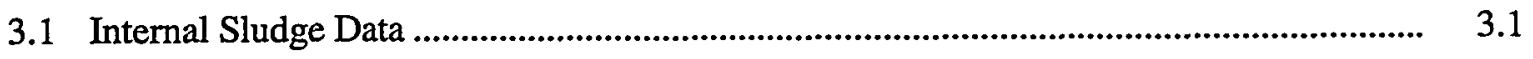

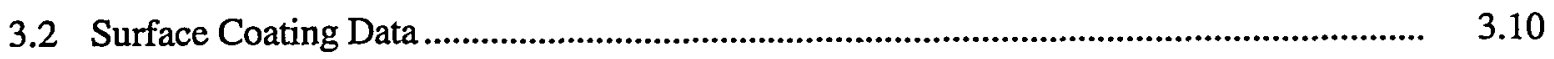

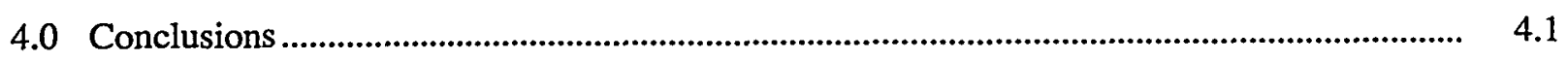

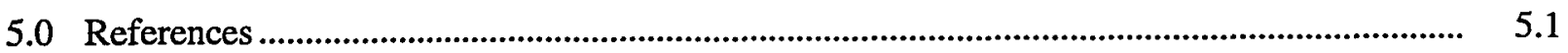

Appendix - Plots of the Drying Results and XRD Spectra of the Internal Sludge and Coating Materials. 


\section{Figures}

2.1 Schematic of the TGA/DSC/MS System

2.2 SNF Element 5427E Showing the Top and Bottom Damaged Areas

2.3 SNF Element 6734U Showing the Damaged Areas at the Midlength and Bottom

2.4 Photomacrograph of Coated SNF Element 0161M

3.1 Plots of Weight Change and Temperature Versus Time for Drying Internal Sludge ssl1

(a) First Run, TGA Run 52 and (b) Rerun, TGA Run 60.

3.2 Plots of Weight Change and Temperature Versus Time for Drying Internal Sludge ss12

(a) First Run, TGA Run 53 and (b) Rerun, TGA Run 59

3.3 Plots of Weight Change and Temperature Versus Time for Drying Internal Sludge ss17

(a) First Run, TGA Run 55 and (b) Rerun, TGA Run 62

3.4 Plots of Weight Change and Temperature Versus Time for Drying the Triplicate

Samples of SNF Internal Sludge ss12

3.5 Plots of Weight Change and Temperature Versus Time for Drying SNF Coating

Sample cs4 (a) First Run, TGA Run 64 and (b) Duplicate Run, TGA Run 63

3.6 Plots of Weight Change and Temperature Versus Time for Drying SNF Coating Sample cs7 (a) First Run, TGA Run 65 and (b) Duplicate Run, TGA Run 66

\section{Tables}

2.1 Description of SNF Internal Sludge and Coating.

3.1 Summary of the SNF Internal Sludge Testing

3.2 Summary of the SNF Element Surface Coating Testing 


\subsection{Introduction}

The corrosion process of the water-stored N-Reactor spent nuclear fuel (SNF) in the Hanford 100-Area K-Basins generated two main products that will influence the water inventory in a packaged Multi-Canister Overpack (MCO). The corrosion products have generated coating deposits on cladding surfaces and trapped sludge in the internal cracks of damaged/corroded SNF elements.

The coating material may have resulted from saturated corrosion products of the uranium core of the SNF, the storage containers which were stainless steel and aluminum (Abrefah 1994), and the structural materials in the basin (steel). The internal sludge material has been generated by extensive fracturing of some of the SNF elements. A fraction of the loose particulates from the spallation of the uranium oxide ends up trapped in the cracked locations of the element. Depending on the pretreatment method used during the SNF conditioning process for preparing the SNF, some of the coating material and the internal sludge will end up in the MCO. A proposed cleaning method for removal of the coating materials from the surfaces of the SNF elements and the loose corrosion products was tested on limited SNF elements (Maassen 1997).

Both the internal sludge (mainly oxides of uranium) and the cladding surface coating material have large surface areas for adsorption/absorption (physically bound) of water in addition to hydrates (chemically bound) that have been identified (uranium oxyhydrates and aluminum hydroxides). The physically and chemically bound water will be the primary source of gaseous product that can pressurize the MCOs during storage. Water released by the oxyhydrates can also react with the exposed metallic uranium of damaged/corroded fuel elements to generate hydrogen during transport, staging, and storage. The Integrated Process Strategy (IPS) (WHC 1995) has developed process steps intended to dry the SNF to an expected product specification prior to sealing it in the MCO for dry storage. The drying behavior of the materials that will be sealed in the MCOs must be determined to ensure that the storage environment does not exceed the storage facility safety basis or design accident analyses. This report discusses a study conducted by Pacific Northwest National Laboratory (PNNL) to evaluate the drying behavior of the internal sludge and the coating material of some K-Basin SNF shipped to the Postirradiation Testing Laboratory for characterization. 


\subsection{Experimental Method}

The SNF internal sludge and coating drying studies were performed using a thermogravimetric system installed in a laboratory at the Radiochemical Processing Laboratory building. The internal sludge samples were collected from three outer $\mathrm{N}$-Reactor fuel elements that were shipped from the K-Basin to the PTL for both destructive and nondestructive examination. A brief discussion of the experimental system and the test samples are in the sections below.

\subsection{TGA/DSC/MS System}

The testing was conducted using a Netzsch STA 409 Thermogravimetric/Differential Scanning Calorimeter/Mass Spectrometer (TGA/DSC/MS) skimmer graphite furnace system. A schematic representation of the TGAJDSC/MS testing system is shown in Figure 2.1. The system is made up of four chambers; a mass spectrometer (MS) chamber, an intermediate chamber, a sample reaction chamber and a balance chamber. The mass spectrometer chamber houses the quadrupole mass spectrometer (QMS) and it is pumped by turbo-molecular pump to a baseline vacuum pressure of about $10^{-7}$ torr. The intermediate chamber separates the MS chamber from the atmospheric reaction chamber and it is pumped by a mechanical pump to a base pressure of about $10^{-3}$ torr without a load. The sample chamber houses a thermogravimetric sample carrier that has the sample thermocouple (i.e., S-type). The sample carrier is connected to the analytical balance. Gas inlet and outlet lines are connected to this chamber to supply the reactant gas. The quartz sample crucible with dimensions of $15 \mathrm{~mm}$ outside diameter, $12 \mathrm{~mm}$ inside diameter, a depth of $7.2 \mathrm{~mm}$, and a height of $9 \mathrm{~mm}$, is mounted at the end of the sample carrier (Figure 2.1). The average tare weight of the sample crucibles was about $1.2 \mathrm{~g}$. The sample chamber is resistively heated by graphite elements that are protected by ultrapure helium gas flow through the element shell chamber. The analytical balance chamber houses the electrobalance and a gas inlet to the chamber that allows it to be purged by either an inert gas or the reactant gas. The temperature of the analytical chamber is maintained at ambient conditions by a series of heat shields in the sample chamber and water cooling at the joint that separates this chamber from the heated sample chamber.

\subsection{Test Samples}

\subsubsection{SNF Internal Sludge Samples}

The SNF internal sludge samples used for the drying studies were taken from the damaged areas of three SNF elements: 5427E, 6743U, and 7913U. Shown in Table 2.1 are the identifications of the internal sludge samples and the SNF elements damaged regions where they were collected. A detailed description of the method used to collect both the internal sludge and the coating samples is given in a report by Pitner (1997). Element 5427E was selected from the K-East Basin and has major damage at both ends as shown in Figure 2.2. The internal sludge sample ssl1 was collected from the top end, sample ssl3 came from the bottom end, and sample ssl 2 was collected from the hanger and may contain particulates from both damage areas. Figure 2.3 shows the damaged midsection and the bottom of SNF element 6743U, taken from the K-West Basin. The internal sludge samples ssl4 and ssl5 were collected from the damaged midsection and bottom of SNF element 6743U, respectively. The other two internal sludge samples (ssl7 and ssl8) were collected from SNF element $7913 \mathrm{U}$ that was also stored at the K-West Basin. 


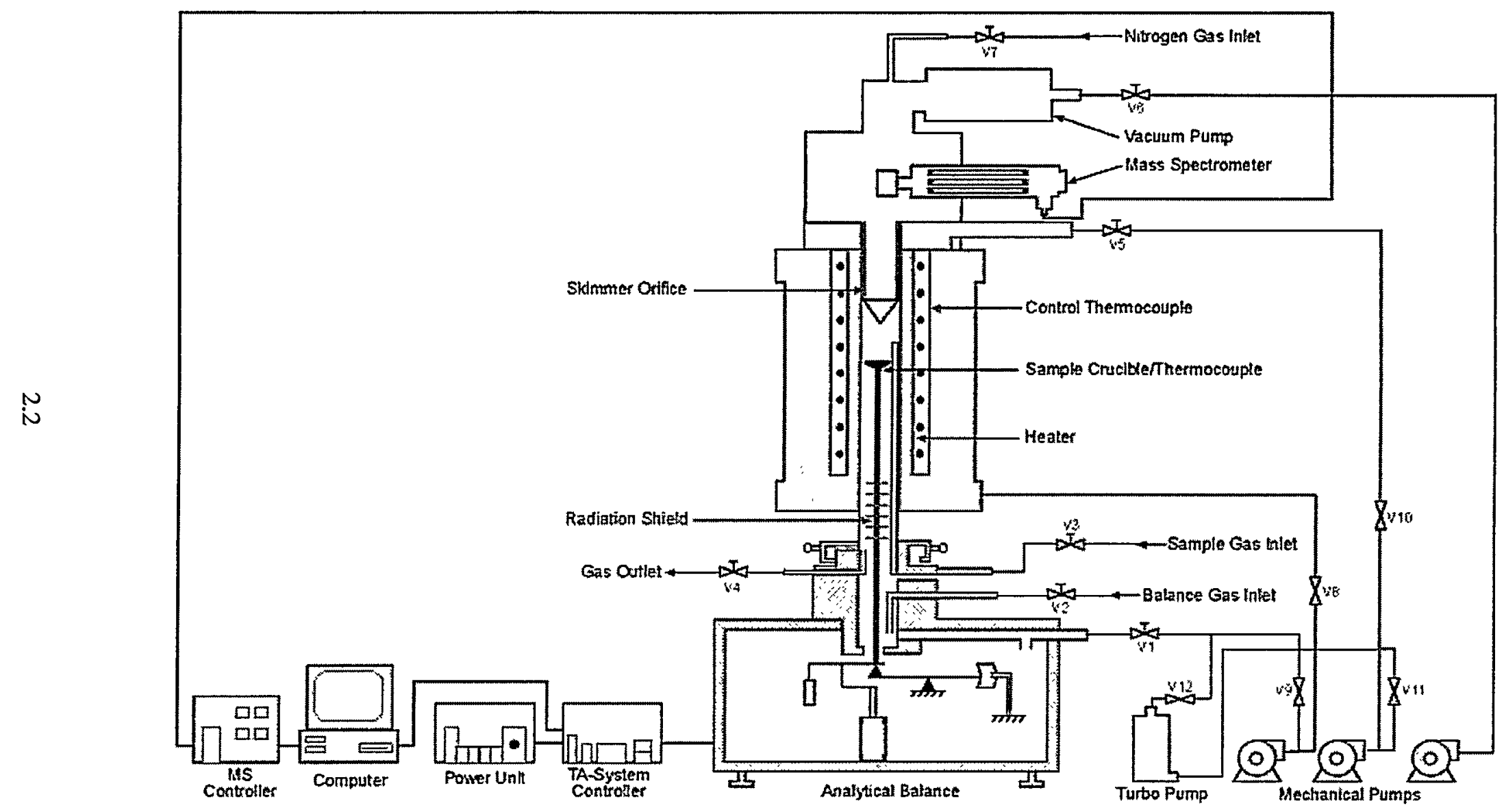

Figure 2.1. Schematic of the TGA/DSC/MS System 
Table 2.1. Description of SNF Internal Sludge and Coating

\begin{tabular}{|c|c|c|c|c|c|}
\hline \multicolumn{3}{|c|}{ SNF Element } & \multicolumn{3}{|c|}{ Internal Sludge/Coating Material } \\
\hline ID (Canister) & Basin & $\begin{array}{l}\text { Canister } \\
\text { Material } \\
\end{array}$ & I & $\begin{array}{c}\text { Region of SNF } \\
\text { Element }\end{array}$ & Description \\
\hline $5427 \mathrm{E}$ & \multirow{3}{*}{$\mathrm{KE}$} & \multirow{3}{*}{ Aluminum } & ssl1 & $\begin{array}{l}\text { Particulates from top } \\
\text { end }\end{array}$ & $\begin{array}{l}\text { Dark/gray powder with } \\
\text { chunks }\end{array}$ \\
\hline 5427E & & & ss12 & $\begin{array}{l}\text { Chunks and particulates } \\
\text { collected from hanger }\end{array}$ & $\begin{array}{l}\text { Dark/gray powder with } \\
\text { chunks }\end{array}$ \\
\hline $5427 \mathrm{E}$ & & & $\operatorname{ssl3}$ & $\begin{array}{l}\text { Particulates from lower } \\
\text { end }\end{array}$ & $\begin{array}{l}\text { Dark/gray powder with } \\
\text { chunks }\end{array}$ \\
\hline $6743 \mathrm{U}$ & \multirow[t]{2}{*}{ KW } & \multirow[t]{2}{*}{$\begin{array}{l}\text { Stainless } \\
\text { Steel }\end{array}$} & ss14 & $\begin{array}{l}\text { Particulates from the } \\
\text { center breach }\end{array}$ & Grayish looking particulates \\
\hline $6743 \mathrm{U}$ & & & ssl5 & $\begin{array}{l}\text { Particulates from the } \\
\text { bottom end }\end{array}$ & $\begin{array}{l}\text { Dark/gray powder with } \\
\text { chunks }\end{array}$ \\
\hline 7913U & \multirow[t]{2}{*}{$\overline{K W}$} & \multirow[t]{2}{*}{$\begin{array}{l}\text { Stainless } \\
\text { Steel }\end{array}$} & ss17 & $\begin{array}{l}\text { Particulates from the } \\
\text { bottom end }\end{array}$ & $\begin{array}{l}\text { Dark/gray powder with } \\
\text { chunks }\end{array}$ \\
\hline $7913 U$ & & & ss18 & $\begin{array}{l}\text { Particulates from the } \\
\text { center breach }\end{array}$ & Dark particulates \\
\hline $0161 \mathrm{M}$ & $\overline{\mathrm{KW}}$ & Aluminum & $\operatorname{cs} 4$ & $\begin{array}{l}\text { Mostly from outer } \\
\text { cladding surface }\end{array}$ & White gray flakes \\
\hline $2667 \mathrm{U}$ & KW & $\begin{array}{l}\text { Stainless } \\
\text { Steel }\end{array}$ & $\operatorname{cs} 7$ & Outer cladding surface & Brownish orange powder \\
\hline
\end{tabular}

\subsubsection{SNF Element Surface Coatings}

The coating samples were taken from the cladding surfaces of two SNF elements that were stored in the K-West Basin. The grayish flake-like coating sample, cs4, was collected from SNF element $0161 \mathrm{M}$ (Figure 2.4), and the orange coating sample, cs7, came from SNF element 2667U.

\subsubsection{Sample Preparation and Testing}

The sample crucibles, fabricated from quartz, measured $15 \mathrm{~mm}$ outside diameter, $12 \mathrm{~mm}$ inside diameter, and $7.2 \mathrm{~mm}$ deep, with an overall height of $9.0 \mathrm{~mm}$. For each TGA run, the crucible was filled with about 100 to $200 \mathrm{mg}$ of either the internal sludge or coating sample, weighed, and mounted on top of the TG sample carrier. Each sample was also videotaped in the Shielded Analytical Laboratory (SAL) hot cell before transfer to the TGA laboratory (Lab. 414) for testing. The test samples were vacuum dried in the TGA system at ambient conditions for about 24 hours as a pretreatment to remove any free water component prior to heating. All the drying tests were performed under vacuum conditions of about $10^{-3}$ torr. The samples were dried over a temperature range of ambient to $550^{\circ} \mathrm{C}$ with a ramp rate of about $0.4^{\circ} \mathrm{C} / \mathrm{min}$. 

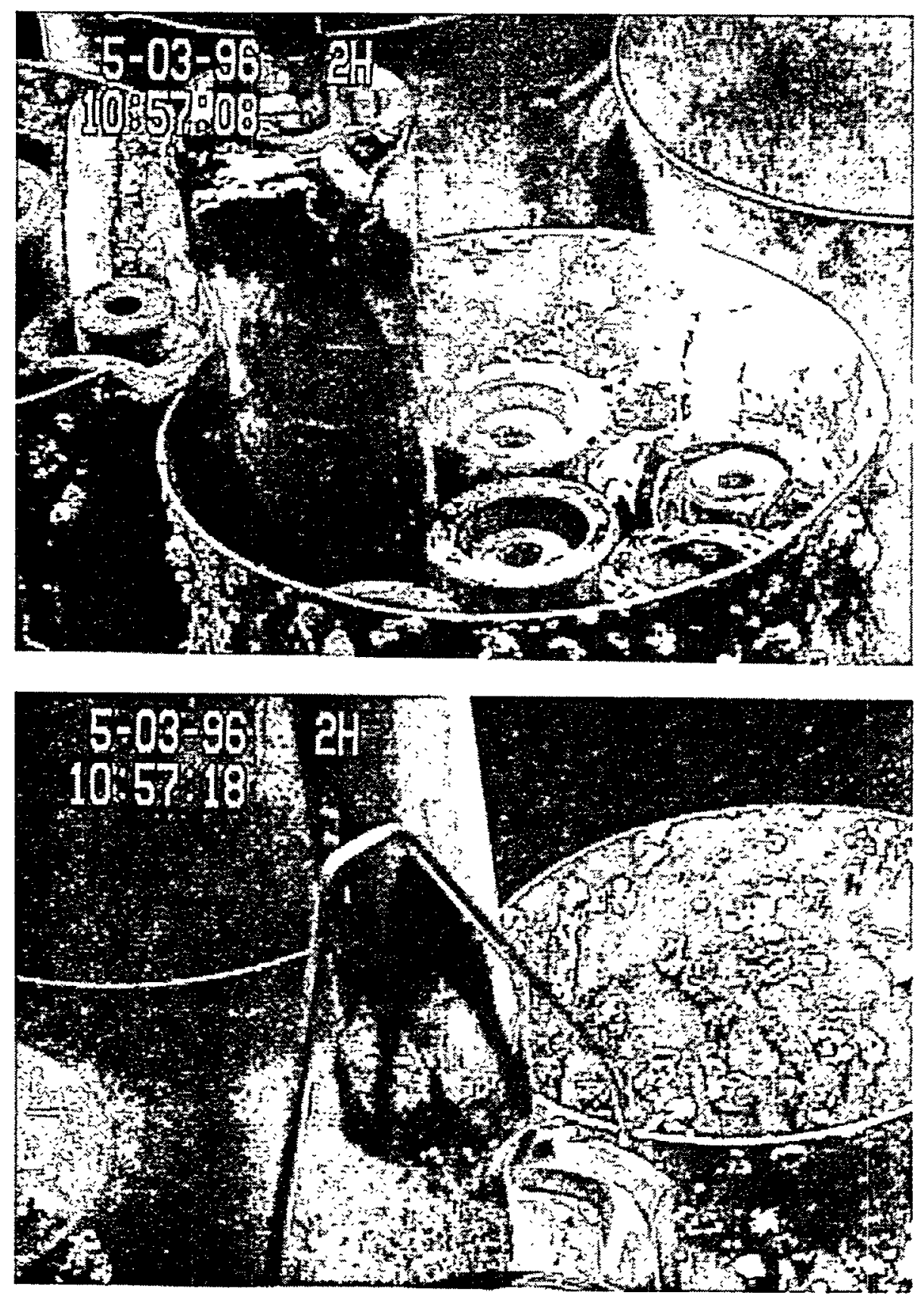

Figure 2.2. SNF Element 5427E Showing the Top and Bottom Damaged Areas 

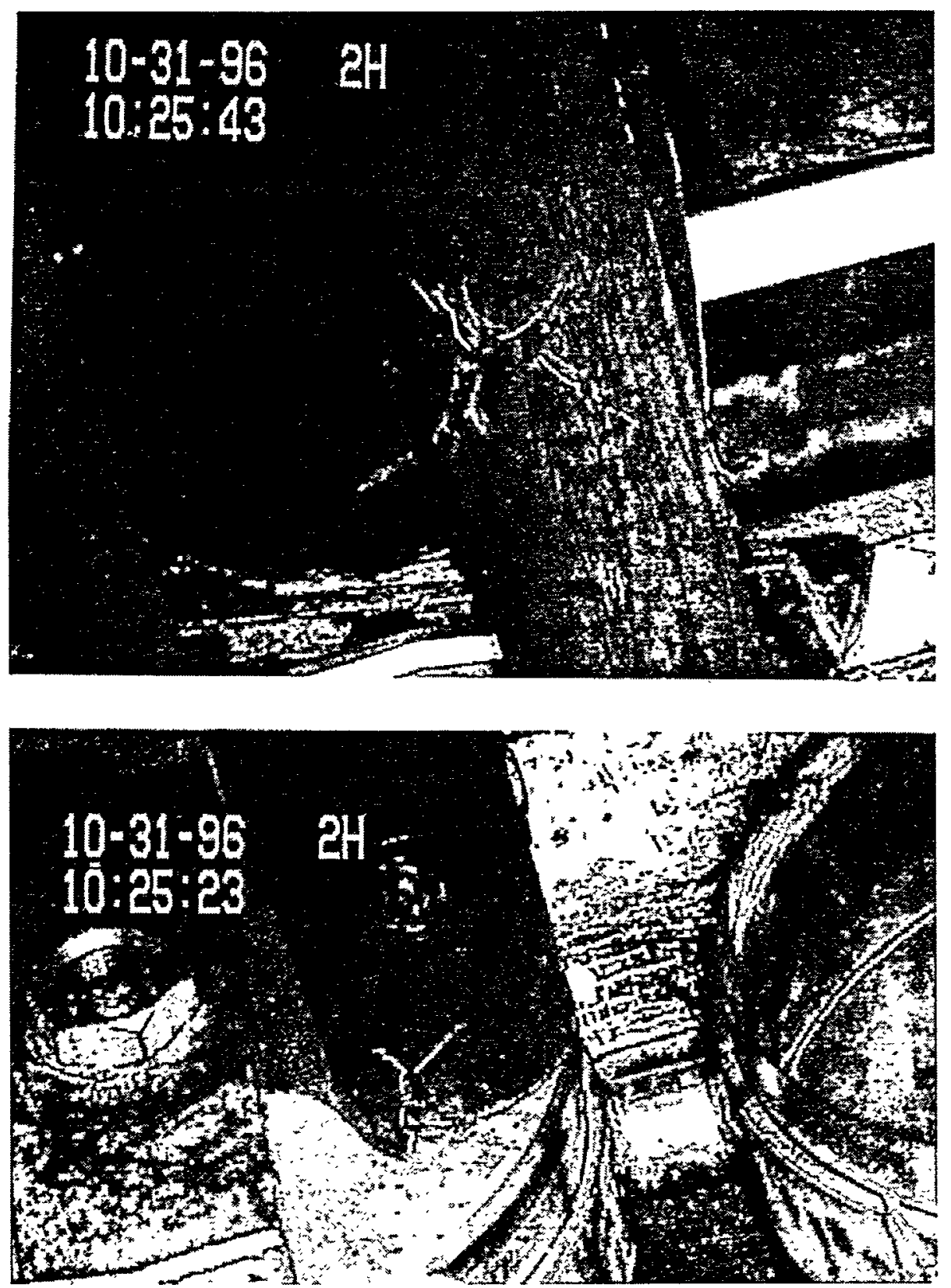

Figure 2.3. SNF Element 6734U Showing the Damaged Areas at the Midlength and Bottom 


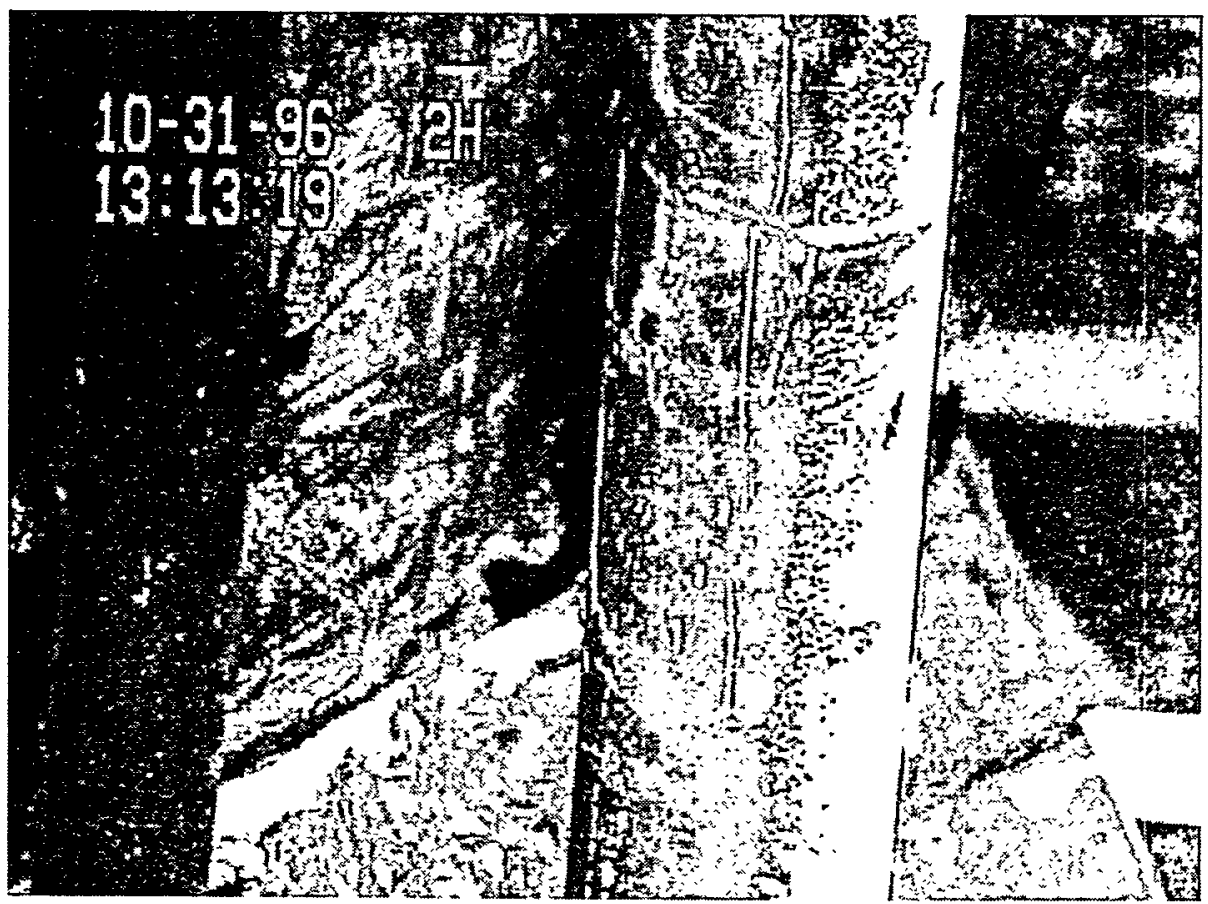

Figure 2.4. Photomacrograph of Coated SNF Element 0161M

Additionally, a sample was taken out of the internal sludge ssl2, homogenized by mixing and crushing in a container (as best as it can be done in a hot cell), and divided into three equal portions for testing. Each of the three ssl2 subsamples was subjected to one of the following three testing processes.

1. Drying in vacuum with a temperature ramp rate of $0.4^{\circ} \mathrm{C} / \mathrm{min}$.

2. Prior oxidation of the internal sludge in vacuum at an isothermal temperature of about $100^{\circ} \mathrm{C}$, sample cooled down to ambient temperature followed by drying in vacuum at a temperature ramp rate of $0.4^{\circ} \mathrm{C} / \mathrm{min}$.

3. Prior oxidation of the internal sludge in air at an isothermal temperature of about $100^{\circ} \mathrm{C}$ and one atmosphere system pressure, then sample cooled down to ambient conditions followed by drying in vacuum at a temperature ramp rate of $0.4^{\circ} \mathrm{C} / \mathrm{min}$.

These last three tests were performed with the objective of possibly separating the oxidation reaction from the thermal decomposition of any hydrated component of the samples. 


\subsection{Analytical Results and Discussion}

Plots of the weight change versus time for the SNF internal sludge drying are shown in Figures 3.1 through 3.4. The summaries of the tests for the internal sludge are listed in Table 3.1. The drying results for the two coating samples cs 4 and cs7 are shown in Figures 3.5 and 3.6 and the weight changes are listed in Table 3.2. Results of the runs not shown in Figures 3.1 through 3.6 are given in the Appendix. The observed slope change for the temperature line may have been caused by the furnace controller.

\subsection{Internal Sludge Data}

Figure 3.1a shows the drying results of SNF internal sludge sample ssl1. This plot represents one of the drying tests in which a small sample size of about $100 \mathrm{mg}$ was used. The sample gained weight for the temperature range (ambient to $543^{\circ} \mathrm{C}$ ) of the test. The weight gain is nonlinear and it is higher at the initial stages but decreased with increasing time and temperature. The total weight gain by the sample is $6.6 \mathrm{mg}$ which is about 6 weight percent of the initial weight (i.e., $104.5 \mathrm{mg}$ ) of the sample. The beforeand after-test weight measurement also yielded a weight gain of about $5.4 \mathrm{mg}$. The drying tests were performed using a crucible without lids and this has made it difficult to transfer the samples between the hot cell (where the weight measurements are performed) and the glove box (where the TGA system is installed for the drying tests) without a loss. Notwithstanding this difficulty, the two weight gain measurements agree very well.

The rerun with larger sample size for the internal sludge sample ssl1 is shown in Figure 3.1b. The sample size was increased in the rerun with the objective of possibly increasing the hydrated fraction of the testing sample. Due to some unknown behavior, either by the sample or the system, the weight change curve for this rerun shows an erratic behavior. Overall the sample shows a net weight gain which is supported by the before- and after-test weight measurement in Table 3.1. There were instances where the weight change (Figure 3.1b) indicated sample weight loss. The first clear indication happened at a temperature of about $200^{\circ} \mathrm{C}$ followed by a second one at about $390^{\circ} \mathrm{C}$.

The drying results of internal sludge sample ssl 2 with an initial weight of about $106.9 \mathrm{mg}$ (almost the same as ssl1 for TGA Run 52, Figure 3.1a) are shown in Figure 3.2a. This ssl2 sample (Figure 3.2a) showed a net weight increase but the shape of its weight gain curve is different compared to that of ssl1 in Figure 3.1a. The ssl2 sample (Figure 3.2a) lost a small amount of weight, about $0.6 \mathrm{mg}$, at the initial stages of the test. This initial weight loss was followed by a continuous weight gain after a temperature of about $150^{\circ} \mathrm{C}$. Also the rate of weight increase for the ssl2 sample is very close to a linear rate whereas that of the ssl1 represents a parabolic behavior. The total weight gain by the ssl 2 sample is $7.5 \mathrm{mg}$ yielding a net weight gain (total weight gain - weight loss) of about $6.9 \mathrm{mg}$. Despite the differences in the shape of the weight change curves (Figures 3.1a and 3.2a), the net weight gains by the two internal sludge samples with initial weight of about $100 \mathrm{mg}$ are very close to each other.

The weight change versus time plot for a rerun sample of ssl2 is shown in Figure 3.2b. The initial weight of this sample was $205.5 \mathrm{mg}$ (i.e., about twice what was used in the first ssl2 run). 


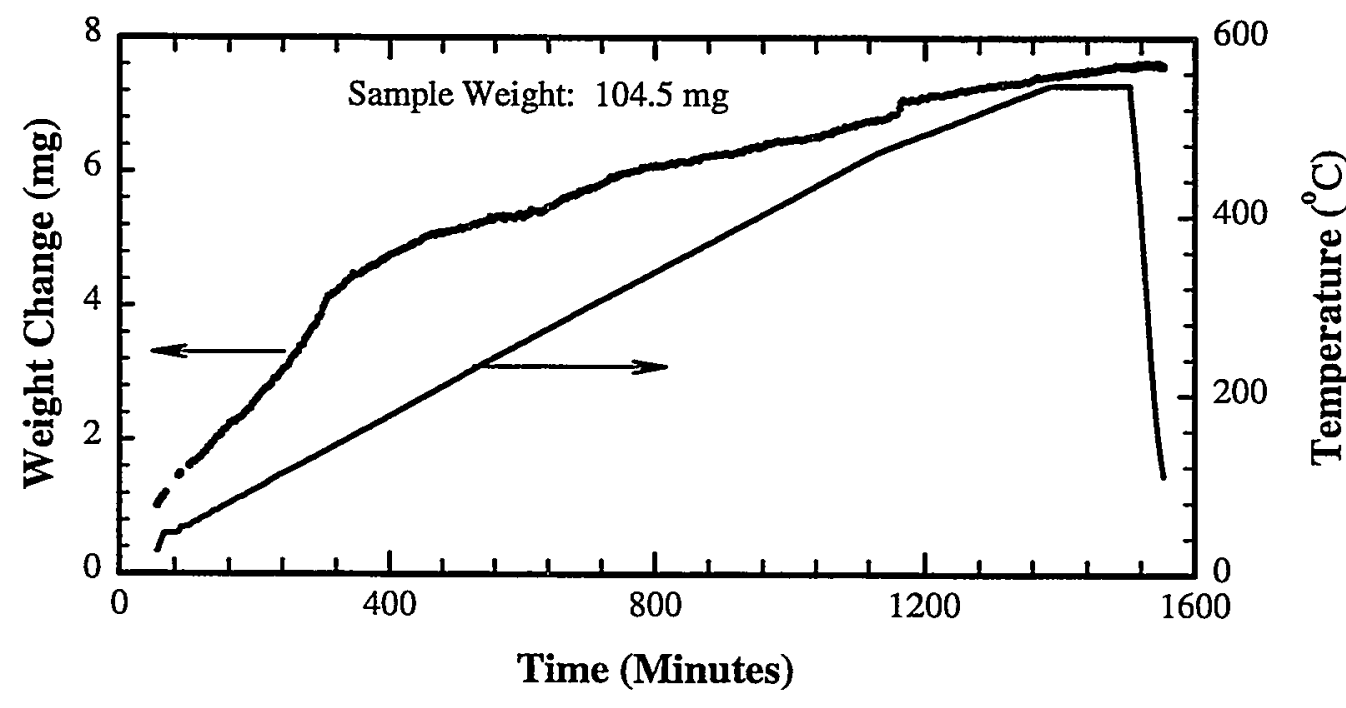

(a)

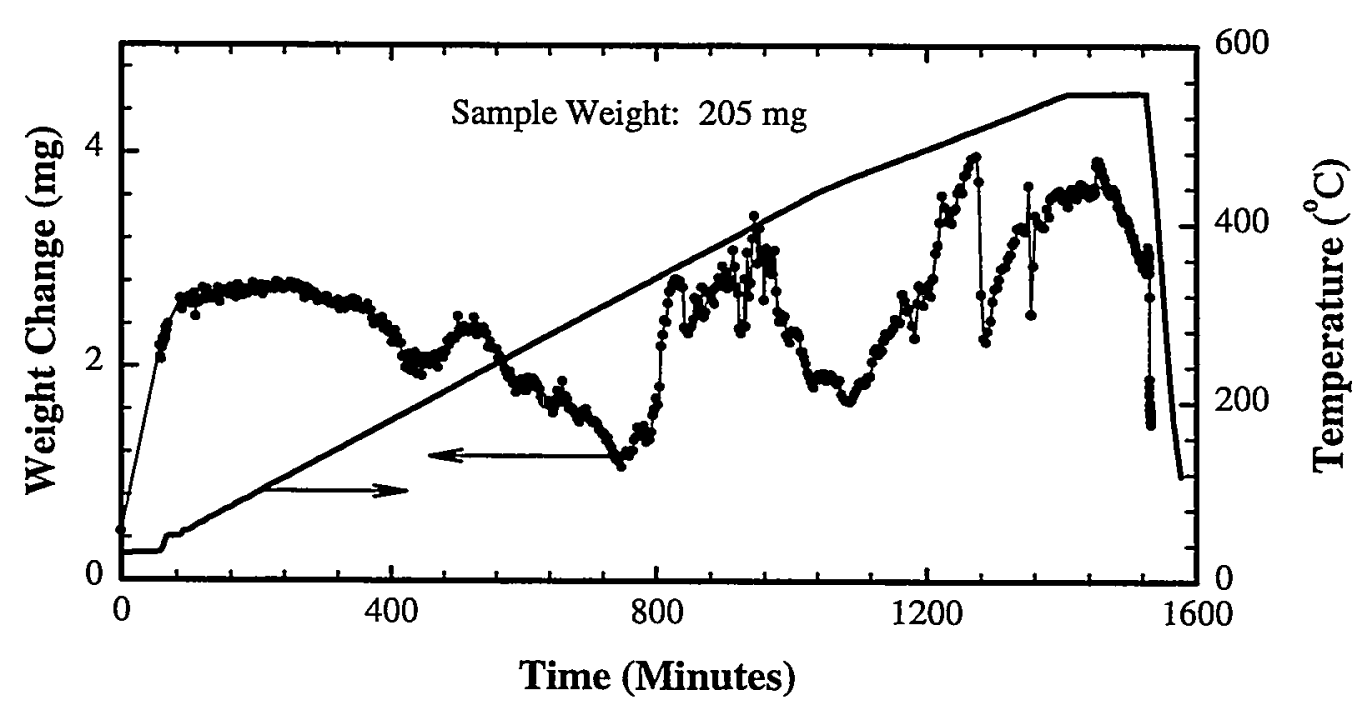

(b)

Figure 3.1. Plots of Weight Change and Temperature Versus Time for Drying Internal Sludge ssl1 (a) First Run, TGA Run 52 and (b) Rerun, TGA Run 60 


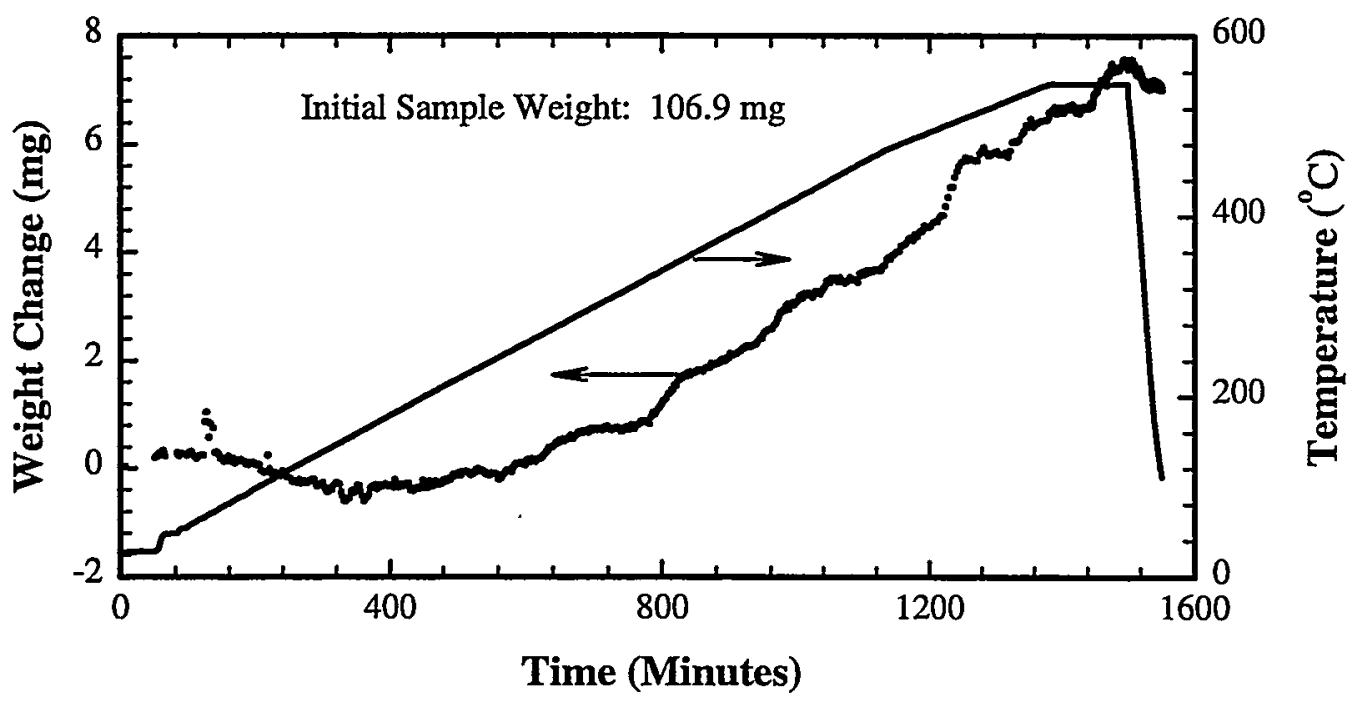

(a)

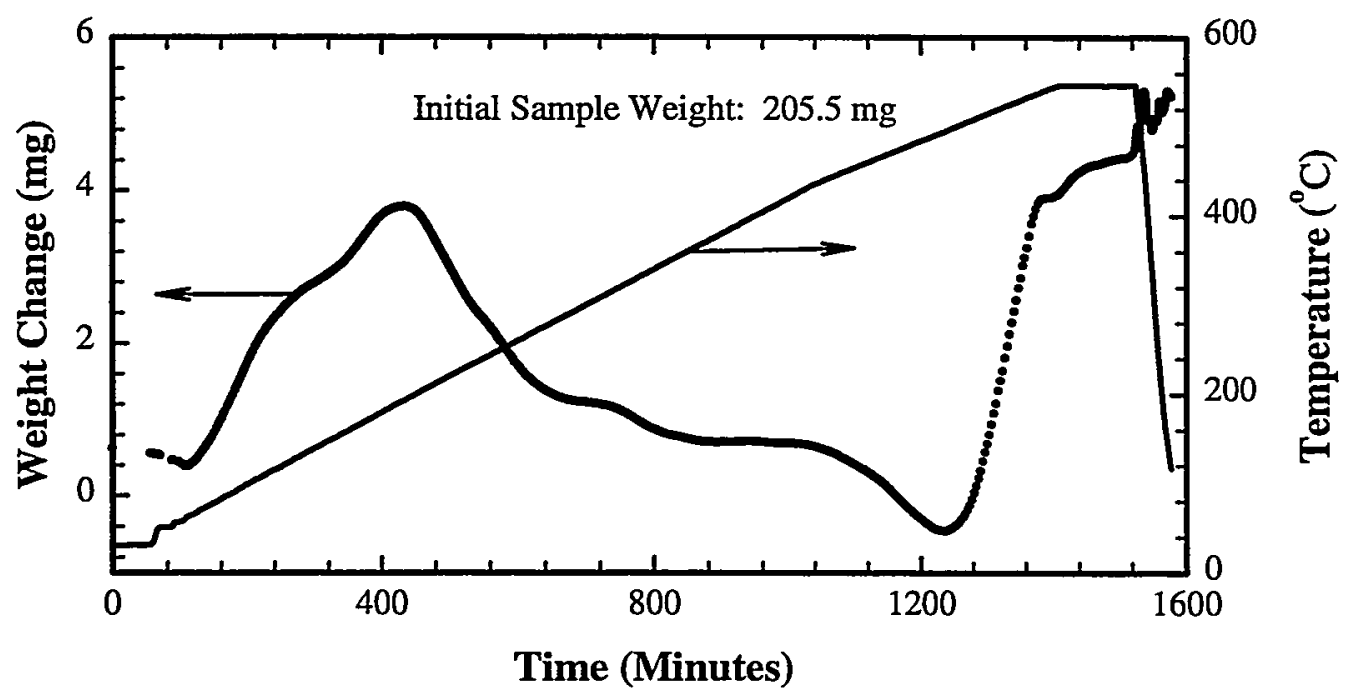

(b)

Figure 3.2. Plots of Weight Change and Temperature Versus Time for Drying Internal Sludge ssl2 (a) First Run TGA Run 53 and (b) Rerun, TGA Run 59 


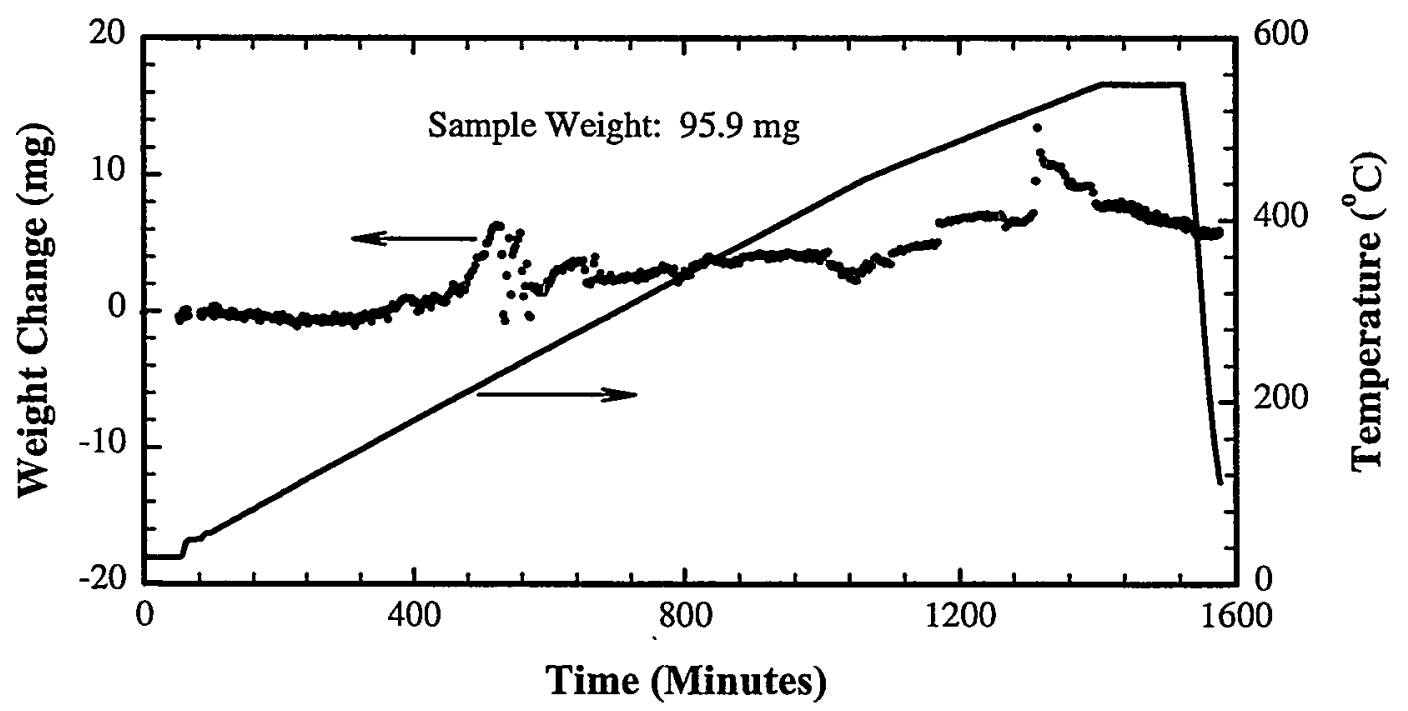

(a)

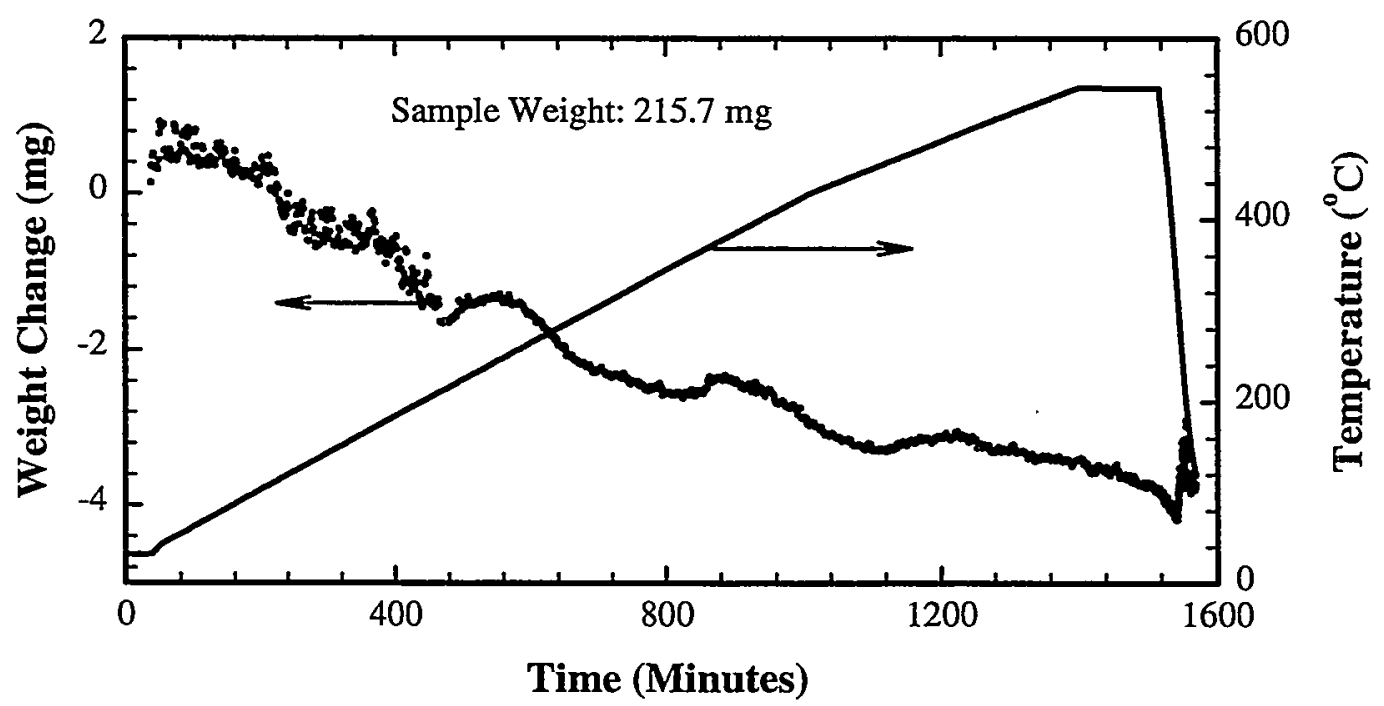

(b)

Figure 3.3. Plots of Weight Change and Temperature Versus Time for Drying Internal Sludge ssl7 (a) First Run, TGA Run 55 and (b) Rerun, TGA Run 62 


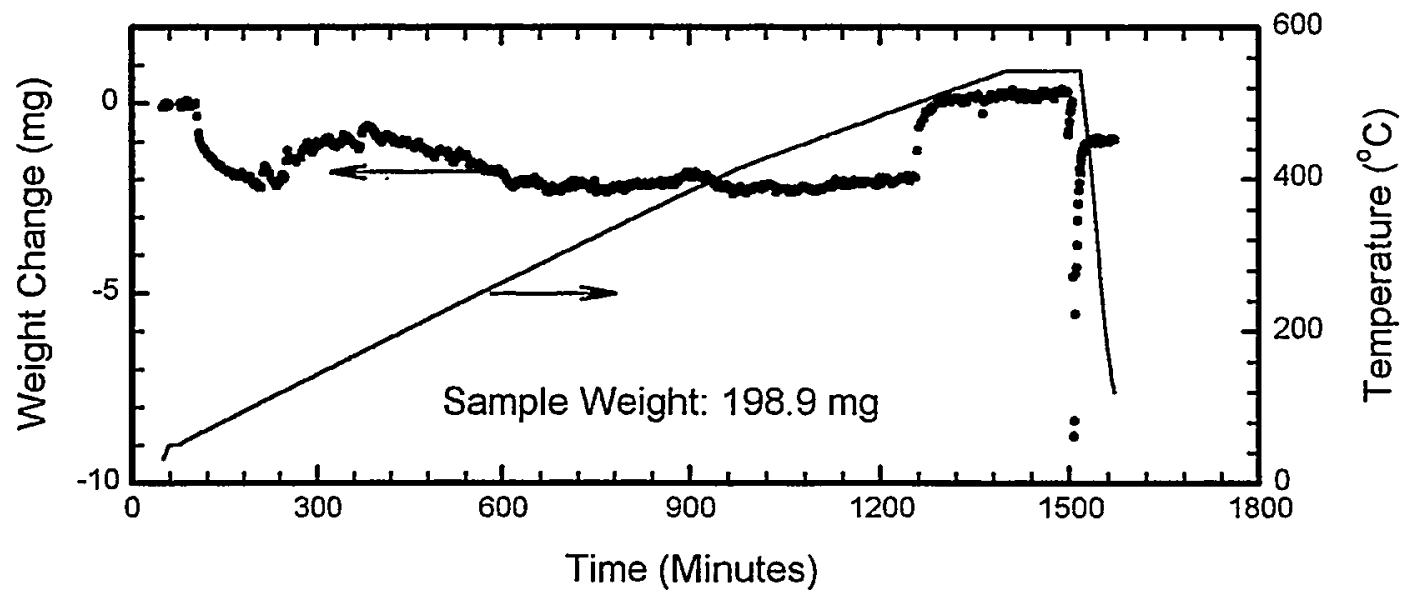

(a)

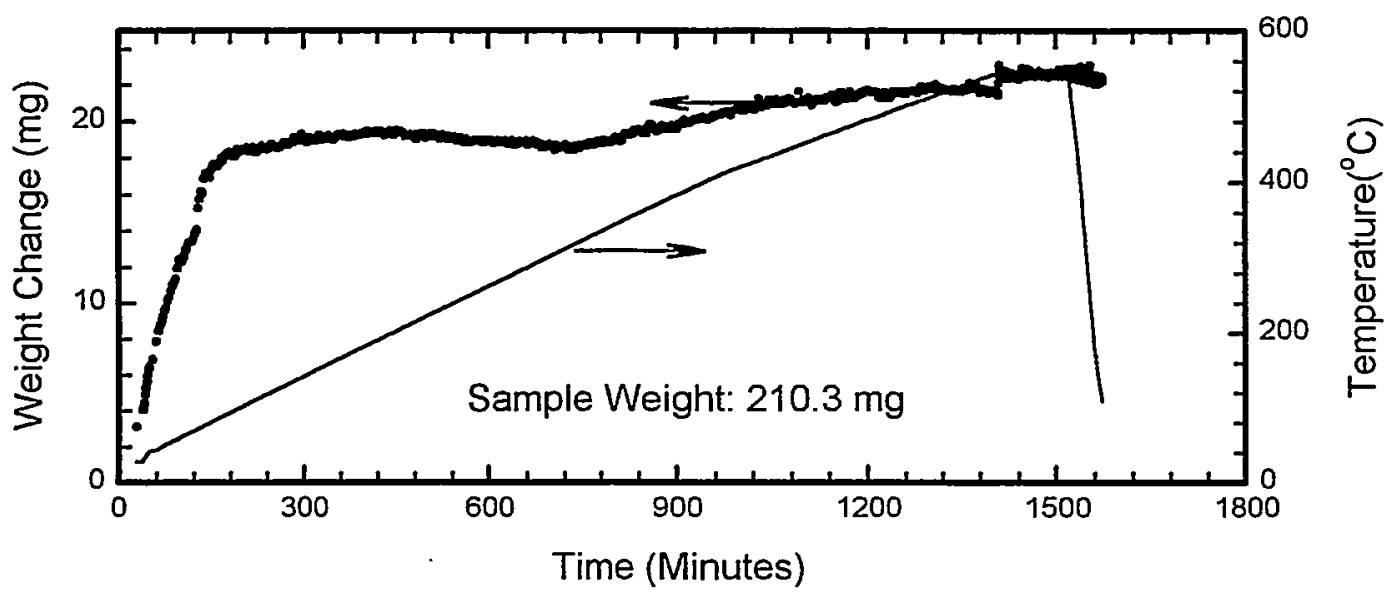

(b)

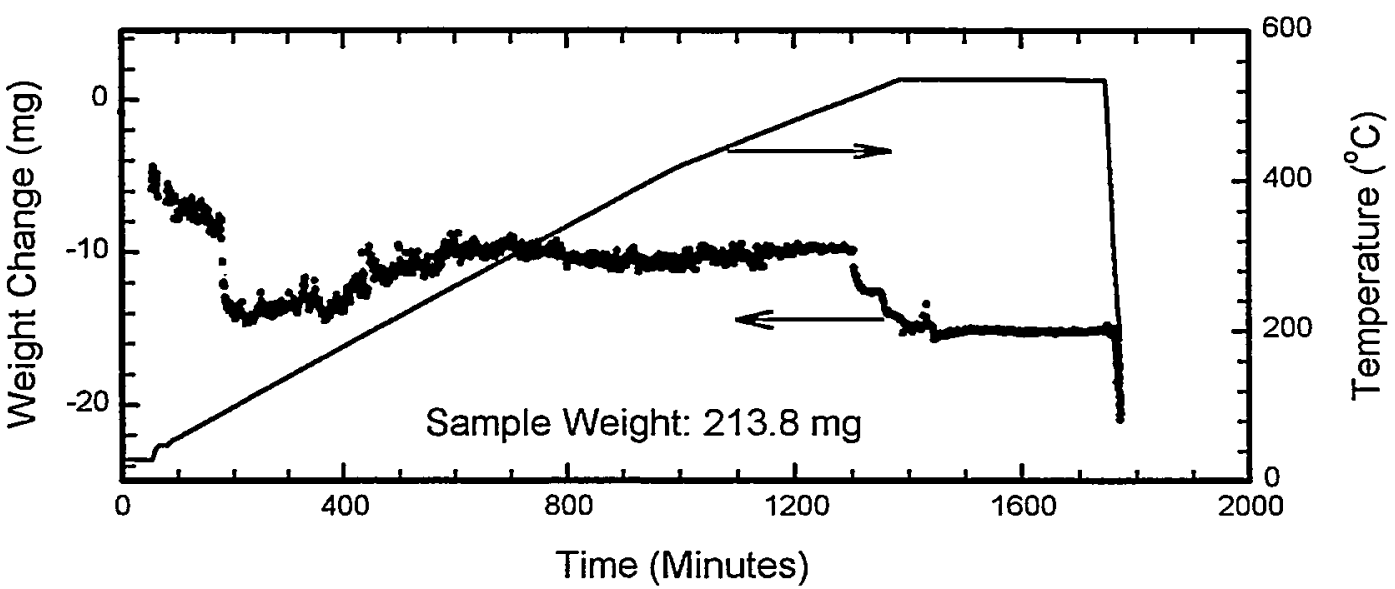

(c)

Figure 3.4. Plots of Weight Change and Temperature Versus Time for Drying the Triplicate Sample of SNF Internal Sludge ssl2; (a) 1 of 3, no prior treatment, TGA Run 67 (b) 2 of 3, prior oxidation of sample in vacuum at about $100^{\circ} \mathrm{C}$, TGA Run 68 and (c) 3 of 3 , prior oxidation in dry air, TGA Run 69. 
Table 3.1. Summary of the SNF Internal Sludge Testing

\begin{tabular}{|c|c|c|c|c|c|c|c|}
\hline \multirow[b]{2}{*}{$\begin{array}{l}\text { TGA } \\
\text { Run }\end{array}$} & \multirow[b]{2}{*}{$\begin{array}{c}\text { Sludge/ } \\
\text { Coating } \\
\text { Run }\end{array}$} & \multicolumn{4}{|c|}{ Sample Characteristics } & \multicolumn{2}{|c|}{$\begin{array}{l}\text { TGA Sample Weight } \\
\text { Change (mg) }\end{array}$} \\
\hline & & ID & $\begin{array}{c}\text { Pre-Test } \\
\text { Weight (mg) }\end{array}$ & $\begin{array}{c}\text { Post-Test } \\
\text { Weight } \\
\text { (mg) }\end{array}$ & $\begin{array}{l}\text { Weight } \\
\text { Loss or } \\
\text { Gain }^{(2)}\end{array}$ & $\begin{array}{l}\text { Weight } \\
\text { Gain(s) }\end{array}$ & $\begin{array}{l}\text { Weight } \\
\text { Loss(es) }\end{array}$ \\
\hline 52 & 1 & ssl1 & 104.5 & 109.9 & +5.4 & 6.60 & --- \\
\hline 53 & 2 & ssl2 & 106.9 & 105.7 & -1.2 & 7.70 & 0.77 \\
\hline 54 & 3 & ssl3 & 95.8 & 101.1 & +5.3 & $-\ldots$ & 18.89 \\
\hline 55 & 4 & ssl7 & 95.9 & 98.0 & +2.1 & 7.37 & 4.83 \\
\hline 56 & 5 & ssl8 & 98.8 & 101.1 & +2.3 & 5.35 & 0.77 \\
\hline 57 & 6 & ssl4 & 104.5 & 107.8 & +3.3 & 14.23 & 4.58 \\
\hline 58 & 7 & ssl5 & 243.3 & 229.1 & -14.2 & 3.87 & 25.37 \\
\hline 59 & 8 & ssl2(Dup) & 205.5 & 196.9 & -8.6 & 3.96 & 4.40 \\
\hline 60 & 9 & ssl1(Dup) & 205.5 & 211.6 & +6.1 & 2.00 & 1.04 \\
\hline 61 & 10 & ssl4(Dup) & 240.3 & 242.9 & +2.6 & N/A & N/A \\
\hline 62 & 11 & ssl7(Dup) & 215.7 & 215.5 & -0.2 & --- & 4.61 \\
\hline 67 & 16 & $\operatorname{ssl} 2(1$ of 3$)$ & 198.9 & $59.1^{(\mathrm{b})}$ & -139.8 & 2.42 & 1.64 \\
\hline 68 & 17 & $\operatorname{ssl} 2(2$ of 3$)$ & 210.3 & 153.6 & -56.7 & 15.40 & 1.06 \\
\hline 69 & 18 & $\operatorname{ssl} 2(3$ of 3$)$ & 213.8 & 160.1 & -53.7 & 4.25 & 9.45 \\
\hline \multicolumn{8}{|c|}{$\begin{array}{l}\text { N/A = no data available. } \\
\text { DUP = rerun. } \\
\text { (a) Before- and After-Test Weight Change. } \\
\text { (b) Lost some of the sample during handling. }\end{array}$} \\
\hline
\end{tabular}

The sample size was increased in the rerun with the assumption that it might yield greater weight loss measurement for the estimate of the fractional component of the sludge that was hydrated. The smoothed weight change curve in Figure $3.2 \mathrm{~b}$ shows a clearly defined segment where the sample lost weight. The weight loss started when the sample temperature reached about $194^{\circ} \mathrm{C}$ and continued until the temperature reached about $495^{\circ} \mathrm{C}$. The total weight loss by the sample for that range in temperature was about $4.3 \mathrm{mg}$. Prior to the segment of weight loss, the sample gained a weight of about $3.8 \mathrm{mg}$. Following the weight loss segment, the sample showed a weight gain. The weight loss in this run occurred at the same temperature range that the duplicate run (TGA Run 60) of sample ssl1 (Figure 3.1b) showed a weight loss. Also it is about the same temperature that the K-East canister sludge drying studies by Abrefah et al. (1998) lost most of the hydrated water by thermal decomposition. The analyses of the decomposition mechanism of the K-East canister sludge together with XRD analysis inferred that the hydrated phase was a uranium trioxide hydrate. The slight similarity between the SNF internal sludge and the canister sludge, and the XRD positive identification of the schoepite phase in two of the internal sludge samples (Jenson 


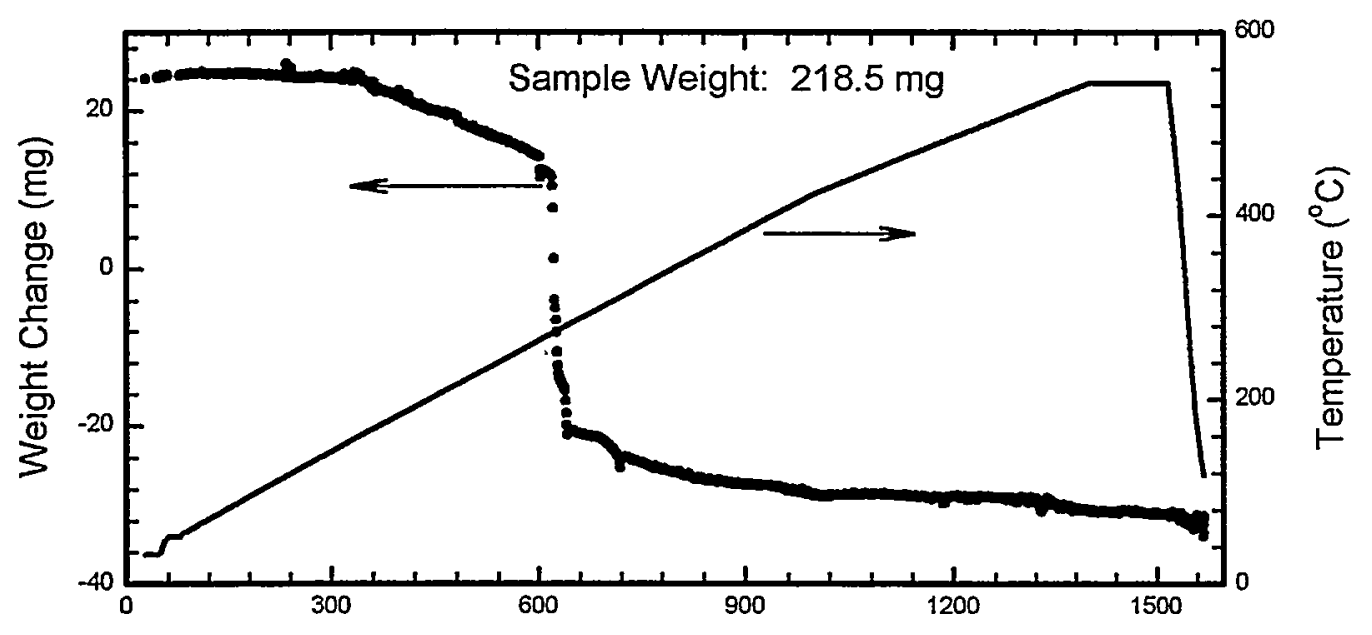

(a)

Time (Minutes)

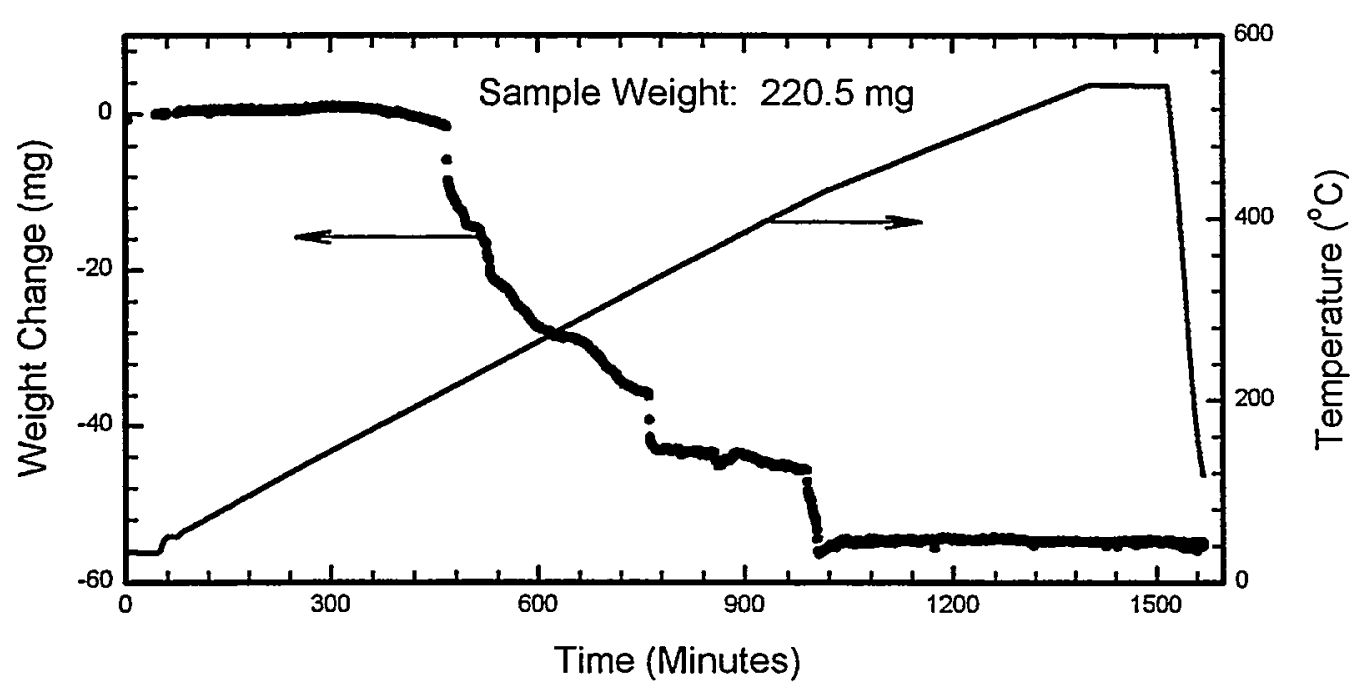

(b)

Figure 3.5. Plots of Weight Change and Temperature Versus Time for Drying SNF Coating Sample cs4 (a) First Run, TGA Run 64 and (b) Duplicate Run, TGA Run 63 


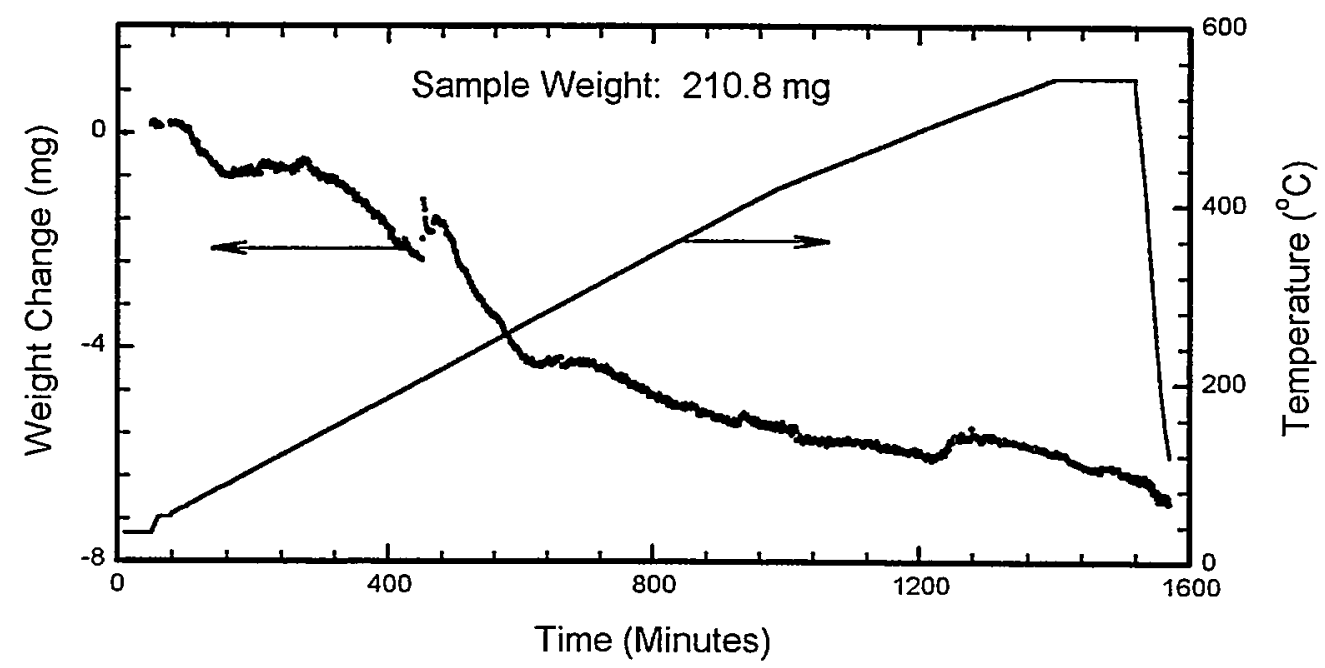

(a)

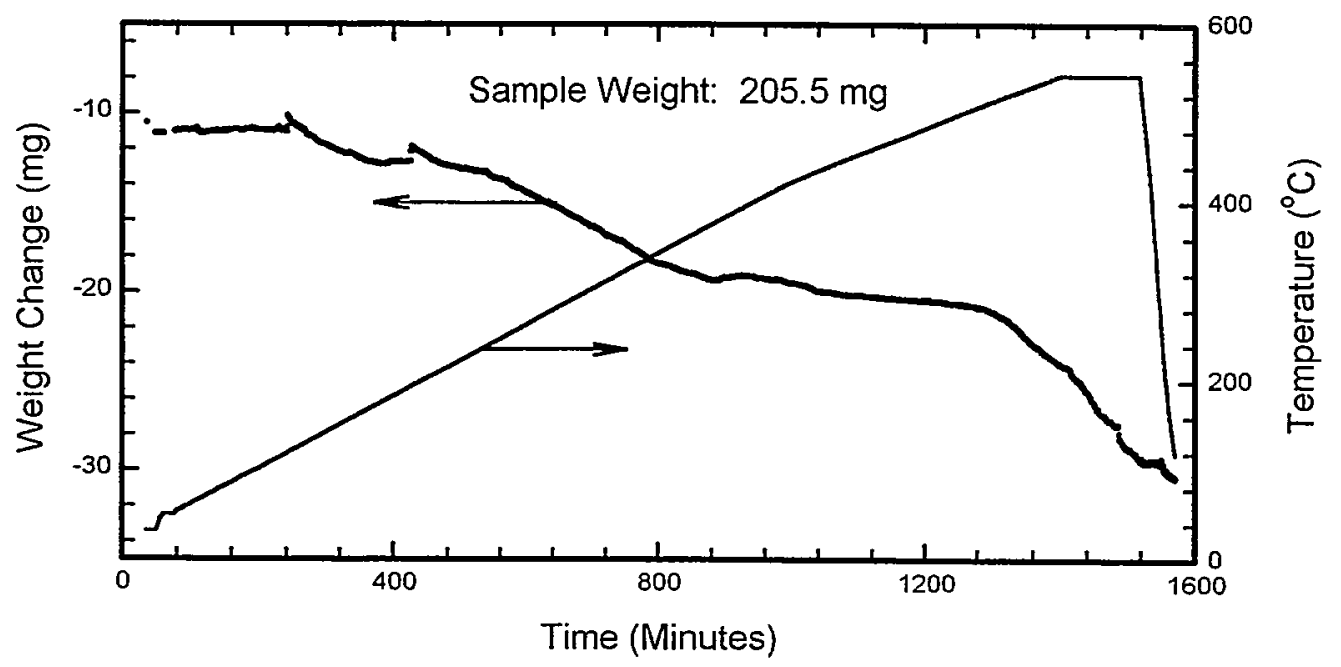

(b)

Figure 3.6. Plots of Weight Change and Temperature Versus Time for Drying SNF Coating cs7 (a) First Run, TGA Run 65 and (b) Duplicate Run, TGA Run 66 
Table 3.2. Summary of the SNF Element Surface Coating Testing

\begin{tabular}{|c|c|c|c|c|c|c|c|}
\hline \multirow[b]{2}{*}{$\begin{array}{l}\text { TGA } \\
\text { Run }\end{array}$} & \multirow[b]{2}{*}{$\begin{array}{c}\text { Sludge/ } \\
\text { Coating } \\
\text { Rurt }\end{array}$} & \multicolumn{4}{|c|}{ Sample Characteristics } & \multicolumn{2}{|c|}{$\begin{array}{l}\text { TGA Sample Weight } \\
\text { Change }\end{array}$} \\
\hline & & I & $\begin{array}{c}\text { Pre-Test } \\
\text { Weight } \\
\text { (mg) }\end{array}$ & $\begin{array}{c}\text { Post-Test } \\
\text { Weight } \\
\text { (mg) }\end{array}$ & $\begin{array}{c}\text { Weight } \\
\text { Loss }{ }^{(a)} \\
(\mathbf{m g})\end{array}$ & $\begin{array}{l}\text { Weight } \\
\text { Loss (mg) }\end{array}$ & $\begin{array}{c}\text { Percent } \\
\text { Weight } \\
\text { Loss }\end{array}$ \\
\hline 63 & 12 & $\operatorname{cs} 4(\text { Dup })^{(b)}$ & 220.5 & 145.9 & 74.6 & 58.4 & 26 \\
\hline 64 & 13 & $\operatorname{cs} 4$ & 218.5 & 138.6 & 79.9 & 56.5 & 26 \\
\hline 65 & 14 & $\operatorname{cs} 7$ & 210.8 & 177.8 & 33.0 & 6.5 & 3 \\
\hline 66 & 15 & cs7 (Dup) & 205.5 & 171.8 & 33.7 & 19.9 & 10 \\
\hline
\end{tabular}

1998), therefore, suggests that the hydrated component of the internal sludge might be the same as the canister sludge (i.e., uranium trioxide hydrate). Above $495^{\circ} \mathrm{C}$, the sample resumed its weight gain behavior and gained about $4.8 \mathrm{mg}$. The observed weight gains may be due to oxidation reaction of the internal sludge with the atmosphere of the TGA system that was about $10^{-3}$ torr. The reactant gas in this case is a mixture of moisture and air. Comparatively, the significant difference between this run (TGA Run 59) and the TGA Run 53 (Figure 3.2a) may be due to sample heterogeneity characteristics. Thus, depending on what fraction is used in the testing, different features relating to reactivity and decomposition may be observed.

Figure 3.3a shows the drying results for the first run (TGA Run 55) using the internal sludge sample ss17. This run showed only small changes in weight. The weight change curve shows an overall weight gain of about $3 \mathrm{mg}$ by the sample, which is in close agreement with the before- and after-test weight gain of about $2.1 \mathrm{mg}$ (Table 3.1). The other significant observation for this run is the small weight loss by the sample at a temperature of about $200^{\circ} \mathrm{C}$. This is the same temperature region where the other internal samples ssl1 (Figure 3.1b) and ssl2 (Figure 3.2b) also showed a weight loss.

The rerun for SNF internal sludge ssl7 with an initial sample weight of $215.7 \mathrm{mg}$ is shown in Figure 3.3b. The weight change curve for this run shows a continuous weight loss by the sample for the entire temperature range. This observed weight loss is different compared to all the previous drying results for internal sludge samples ssl1 (Figures 3.1a and 3.1b) and ssl2 (Figures 3.2a and 3.2b). Also the weight change behavior is different compared to that of the similar ssl7 sample in Figure 3.3a (TGA Run 55). However, the total weight loss by this ssl7 sample, about $4.2 \mathrm{mg}$, compares favorably with the observed weight losses by the reruns of ssl1 (Figure 3.1b) and ssl2 (Figure 3.2b). The observed differences in the weight change behavior for each TGA run supports the inference of sample heterogeneity. The observed differences from run to run may be due to difficulty in measuring very small changes within a noisy signal. Since only small sample sizes of the sludge were tested, the sample heterogeneity behavior adds another degree of difficulty in analyzing the internal sludge data. 
Three additional experiments were performed with the objective of understanding and if possible, separating out the oxidation process from possible thermal decomposition reactions. The drying results for these three tests are shown in Figure 3.4. In Figure 3.4a is shown the weight change curve for the ssl2 sample that was not pretreated but was heated in vacuum at the ramp rate of $0.4^{\circ} \mathrm{C} / \mathrm{min}$. The weight change shows characteristics similar to the other drying curves of Figures 3.1 and 3.2. That is, the internal sludge samples showed both weight gains and losses. The results plotted in Figure $3.4 \mathrm{~b}$ are for the ssl2 sample that was preoxidized in vacuum $\left(10^{-3}\right.$ torr) at about $100^{\circ} \mathrm{C}$ before the temperature was ramped from ambient to $550^{\circ} \mathrm{C}$ for the drying studies. This ssl2 sample showed more weight gain than the untreated sample (Figure 3.4a). But the expanded plot of a segment of the weight gain curve (Figure A.4) clearly shows a weight loss by the sample starting at a temperature of about $200^{\circ} \mathrm{C}$. In Figure $3.4 \mathrm{c}$, the $s s 12$ sample was oxidized in dry air at about $100^{\circ} \mathrm{C}$ before the drying studies were performed in vacuum at the same ramp rate as the others. The prior oxidation process seems to have reduced the oxidation reaction of the sample during the drying run, but failed to give a well-defined weight loss measurement that can be ascribed only to dehydration reaction.

\subsection{Surface Coating Data}

Figures $3.5 \mathrm{a}$ and $3.5 \mathrm{~b}$ show the drying results of two duplicate runs using the SNF coating sample cs4. The samples in both runs lost weight. The weight loss was due to thermal decomposition of a hydrated compound. In Figure 3.5a, the sample lost about $58.4 \mathrm{mg}$ (i.e., 26 weight percent based on the initial weight of the sample). The duplicate run in Figure $3.4 \mathrm{~b}$ shows a weight loss of about $56.5 \mathrm{mg}$ that is also 26 weight percent of the initial sample weight. Thus in both runs, each coating sample lost the same percent of its initial weight suggesting a good reproducibility of the tests. The good agreement between the two runs also suggests that the coating sample was a homogeneous sample.

The weight loss curve of Figure 3.5b (TGA Run 64) was smoothed and differentiated to generate a moisture-release curve in Figure A.6. The temperature-differentiated curve yielded two major peaks at temperatures of $117^{\circ} \mathrm{C}$ and $274^{\circ} \mathrm{C}$. The grayish coating sample (cs4) transformed into white alumina color after drying. This observation suggests that the initial coating sample was aluminum hydroxide, $\mathrm{Al}(\mathrm{OH})_{3}$.

The decomposition reaction for the $\mathrm{Al}(\mathrm{OH})_{3}$ is

$$
2 \mathrm{Al}(\mathrm{OH})_{3} \rightarrow \mathrm{Al}_{2} \mathrm{O}_{3}+3 \mathrm{H}_{2} \mathrm{O}
$$

The above equation gives a theoretical weight loss of 35 weight percent which is greater than what was measured for the two coating samples. The difference can be due to impurities in the testing samples.

The results for two runs using the reddish brown coating cs7 are shown in Figure 3.6. In Figure 3.6a, the sample lost about $6.5 \mathrm{mg}$, but a second run using a duplicate (Figure 3.6b) sample of the cs7 coating showed a weight loss about $19.9 \mathrm{mg}$. The two weight losses constitute about 3 weight percent and 10 weight percent of the initial weight of the samples for TGA Runs 65 and 66, respectively. In particular, the substantial high-temperature weight loss in Figure 3.6b (TGA Run 66) is not seen in Figure 3.5a (TGA Run 65). If the difference between the two runs is accurate, then it may be due to sample 
heterogeneity caused by either impurities or a mixture of different hydrated iron oxides. The data supporting the impurity effect is the identification of calcite $\left(\mathrm{CaCO}_{3}\right)$ in sample cs8 which was a sibling sample of cs7 by an XRD analysis (Jenson 1998). The XRD spectrum of the reddish coating sample cs8, Figure A.11, identified the material to be hydrated iron oxide with an impurity of calcite $\left(\mathrm{CaCO}_{3}\right)$. Having a calcite phase in the sample used for TGA Run 65 will lower the hydrated fraction and consequently yield a lower weight loss measurement. The hypothesis of having a mixture of different hydrated iron oxides is supported by XRD spectrum of similar coating material, cs2, taken from SNF element 6743U. The spectrum of the cs 2 sample is shown in Figure A.12 together with the stick figures that show all the probable chemical phases. However, the observed weight loss difference in the two runs, TGA Run 65 (Figures 3.6a) and TGA Run 66 (Figure 3.6b) may be ascribed to the impurity effect since the cs8 sample came from the same SNF element surface. If the cs7 samples used in the runs have the same chemical phase constituent as the XRD analyzed cs8 sample, then the weight loss measured was due to thermal decomposition of the $\mathrm{FeO}(\mathrm{OH})$. The decomposition reaction is

$$
2 \mathrm{FeO}(\mathrm{OH}) \rightarrow \mathrm{Fe}_{2} \mathrm{O}_{3}+\mathrm{H}_{2} \mathrm{O}
$$

The maximum theoretical weight loss for the above reaction is 20 weight percent of the initial sample weight. 


\subsection{Conclusions}

The SNF internal sludge has a fraction that was reactive and readily oxidized by the background gas in a vacuum of about $10^{-3}$ torr. The oxidation reaction occurred within the entire test temperature range of ambient to $550^{\circ} \mathrm{C}$. The weight gain associated with the oxidation reaction made it difficult to ascertain the decomposition characteristics of the internal sludge. However, at certain periods of the runs, and in some cases, the internal sludge samples lost weight that was attributed to thermal decomposition of certain hydrated fractions of the sludge; and, the decomposition occurred within the test temperature range.

For most cases, the observed weight loss by the SNF internal sludge started at a temperature of about $200^{\circ} \mathrm{C}$. At about the same temperature, the K-East canister sludge thermal decomposition curves showed a major peak temperature suggesting that the hydrated component of the internal sludge may be the same as was identified for the $\mathrm{K}$-East canister sludge, uranium trioxide hydrate. This inference is supported by an XRD identification of a schoepite phase (i.e., $\mathrm{UO}_{3} \cdot 2 \mathrm{H}_{2} \mathrm{O}$ ) in the samples ssl3 and ssl2.

The coating sample cs 4 yielded the highest moisture content of all the corrosion products tested. It lost about 26 weight percent of its initial weight. The decomposition characteristics and the color of the dried sample suggest that the initial material may be aluminum hydroxide, $\mathrm{Al}(\mathrm{OH})_{3}$. The thermal decomposition of this sample started at temperatures slightly above $100^{\circ} \mathrm{C}$ and showed two major decomposition peaks at temperatures $117^{\circ} \mathrm{C}$ and $274^{\circ} \mathrm{C}$. The decomposition reaction was essentially completed within the test temperature range of ambient to $550^{\circ} \mathrm{C}$.

The reddish brown coating sample, cs7, has more moisture content (i.e., weight percent) than the internal sludge samples but less than the aluminum hydroxide sample (cs4). XRD analysis of this coating (Jenson 1998) identified a hydrated iron oxide as the main chemical phase. The decomposition reaction of this coating started below $100^{\circ} \mathrm{C}$ and the process was completed within the tested temperature range. 


\subsection{References}

Abrefah, J., T. A. Thornton, L. E. Thomas, F. M. Berting, and S. C. Marschman. 1994. Characterization Plan for Hanford Spent Nuclear Fuel. PNL-10210, Pacific Northwest Laboratory, Richland, Washington.

Abrefah, J., H. C. Buchanan, and S. C. Marschman. 1998. Drying Behavior of K-East Canister Sludge. PNNL-11628, Pacific Northwest National Laboratory, Richland, Washington.

Jenson, E. D. 1998. XRD Examination of CS Samples. Letter report 28964-02. Pacific Northwest National Laboratory, Richland, Washington.

Maassen, D. P. 1997. Testing of Sludge Coating Adhesiveness on Fuel Elements in 105-K West Basin. HNF-SD-SNF-TRP-020, Duke Engineering \& Services Hanford, Richland, Washington.

Newsome, J. W., H. W. Heiser, A. S. Russell, and H. C. Stumpf. 1960. Alumina Properties. Technical Paper No. 10, 2nd Rev., Aluminum Company of America, Pittsburgh, Pennsylvania.

Pitner, A. L. 1997. K Basin Fuel Subsurface Examinations and Coating Sampling. HNF-SD-SNF-TI060, Duke Engineering \& Services Hanford, Richland, Washington.

WHC. 1995. Integrated Process Strategy for K Basins Spent Nuclear Fuel. Volume 1: Strategy and Recommendations, WHC-SD-SNF-SP-005, Vol. 1, Rev 0 (July 1995), Westinghouse Hanford Company, Richland, Washington. 


\section{Appendix}

Plots of the Drying Results and XRD Spectra of the Internal Sludge and Coating Materials 


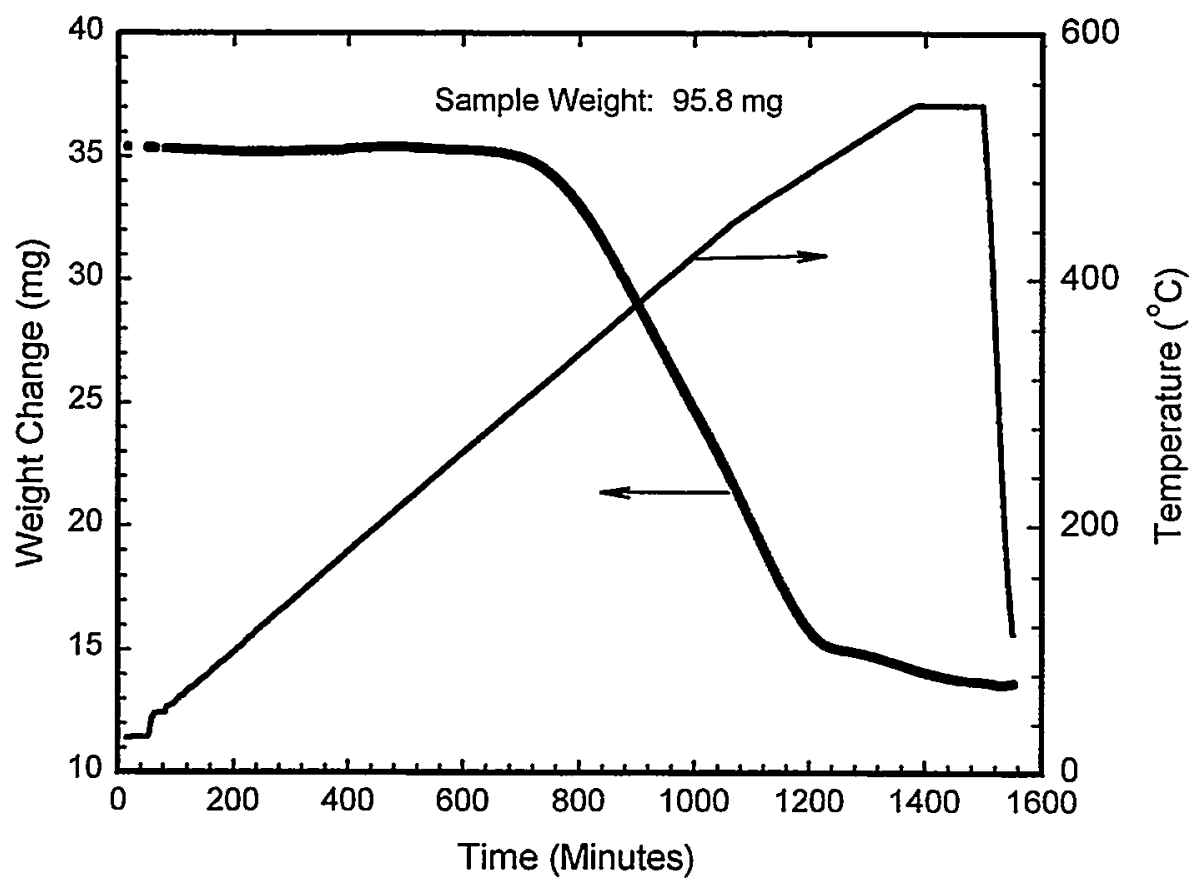

Figure A.1. Plot of Weight Change (smoothed to remove noisy signals) and Temperature Versus Time for Drying Internal Sludge ss13, TGA Run 54

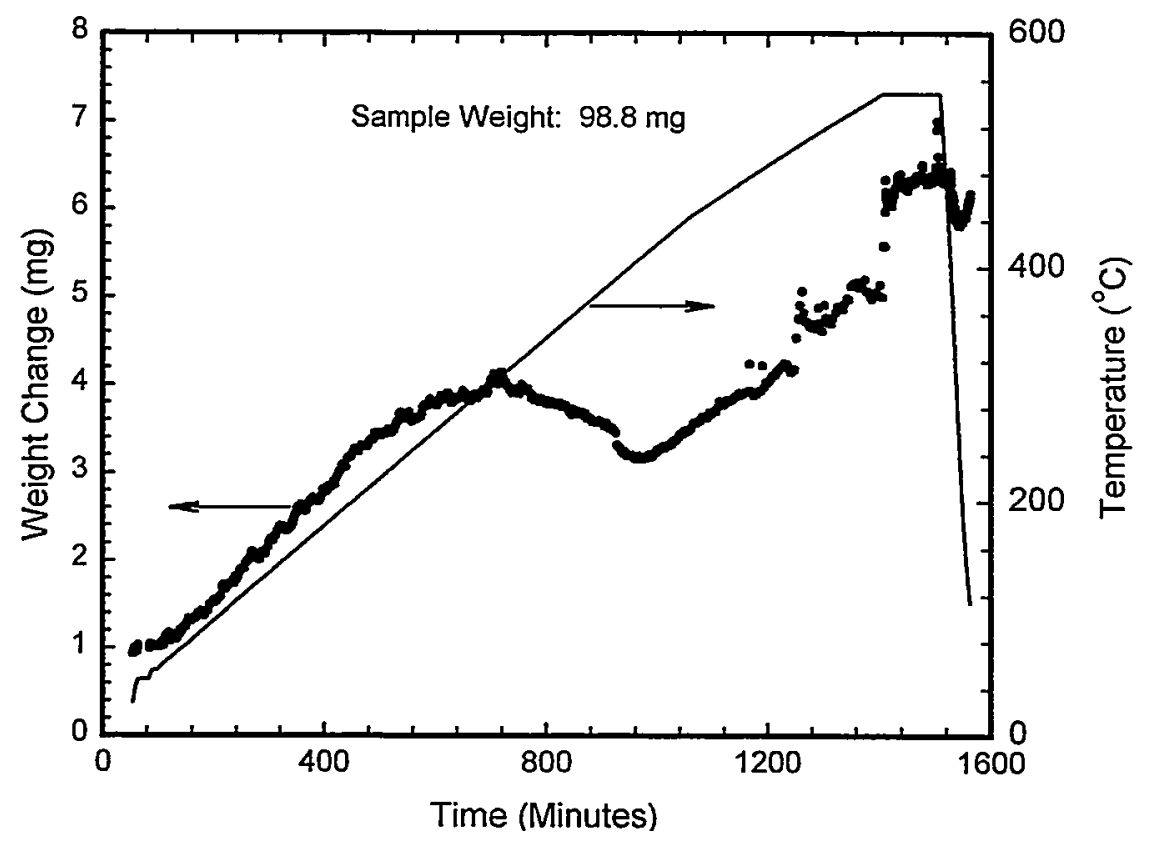

Figure A.2. Plot of Weight Change and Temperature Versus Time for Drying Internal Sludge ss18, TGA Run 56 


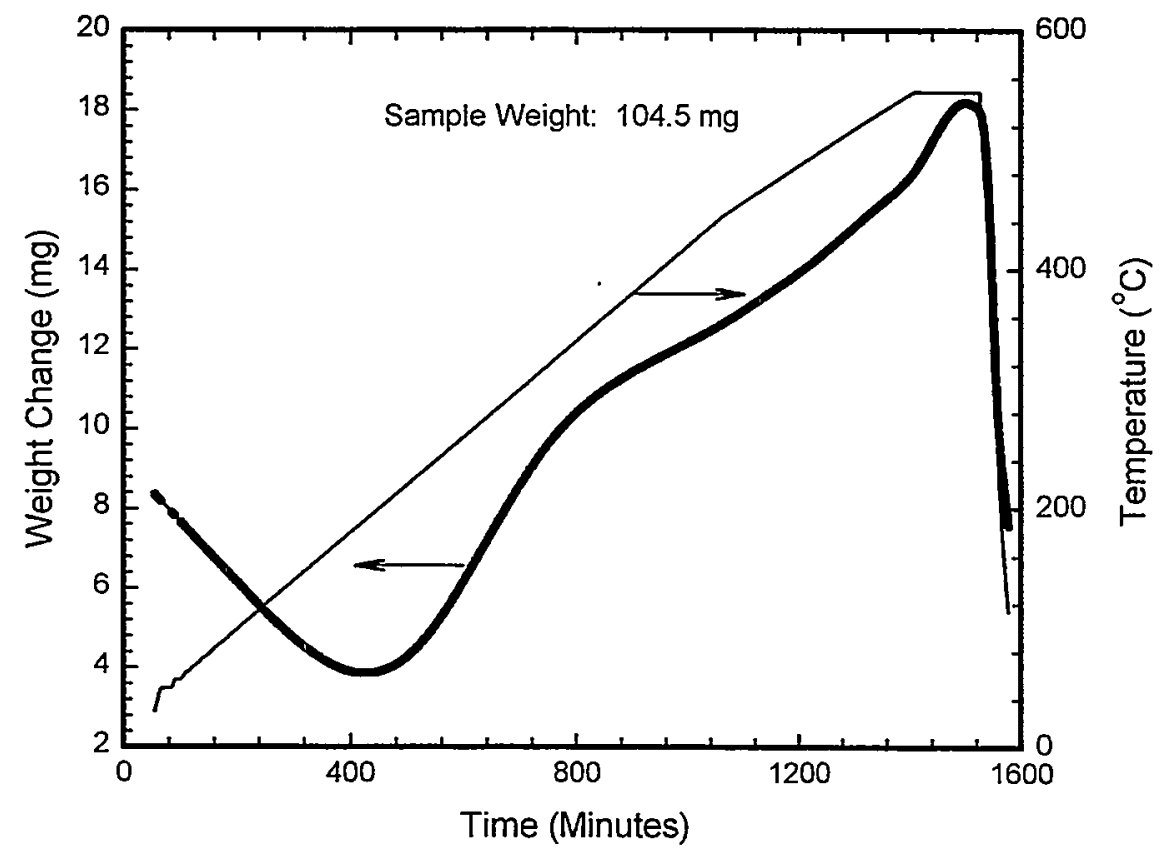

Figure A.3. Plot of Weight Change (smoothed to remove noisy signals) and Temperature Versus Time for Drying Internal Sludge ssl4, TGA Run 57

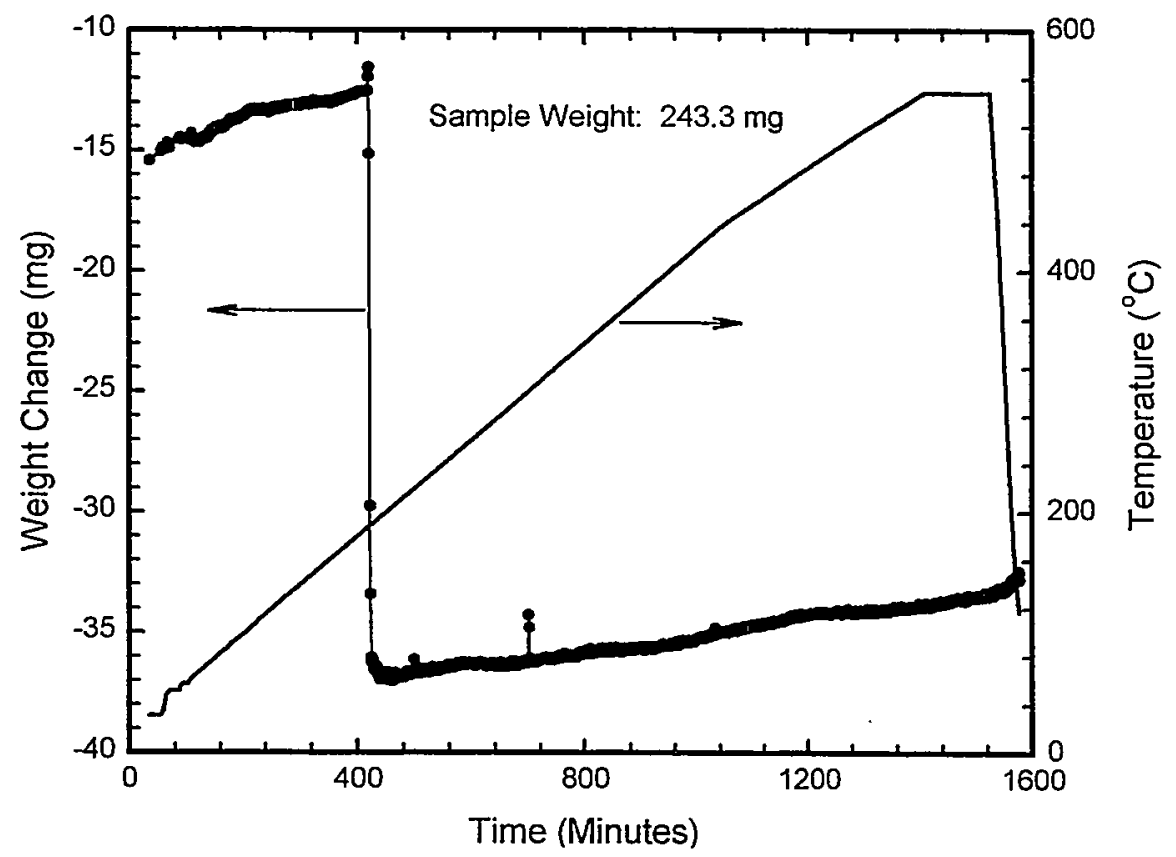

Figure A.4. Plot of Weight Change and Temperature Versus Time for Drying Internal Sludge ss15, TGA Run 58 


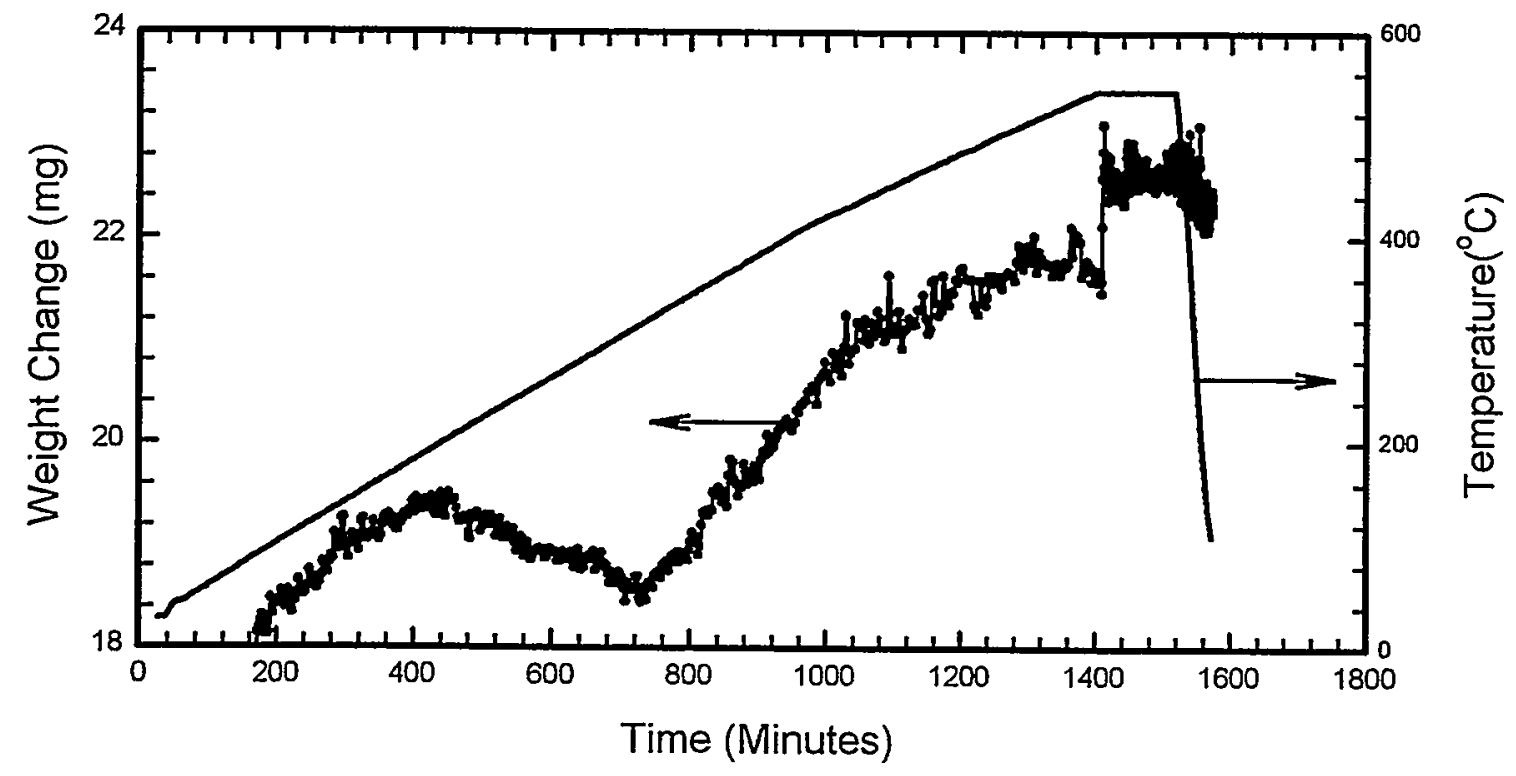

Figure A.5. Plot of Weight Change and Temperature Versus Time for Drying Internal Sludge ssl2 (2 of 3) for TGA Run 68 Showing Segment of the Run Where the Sample Lost Weight

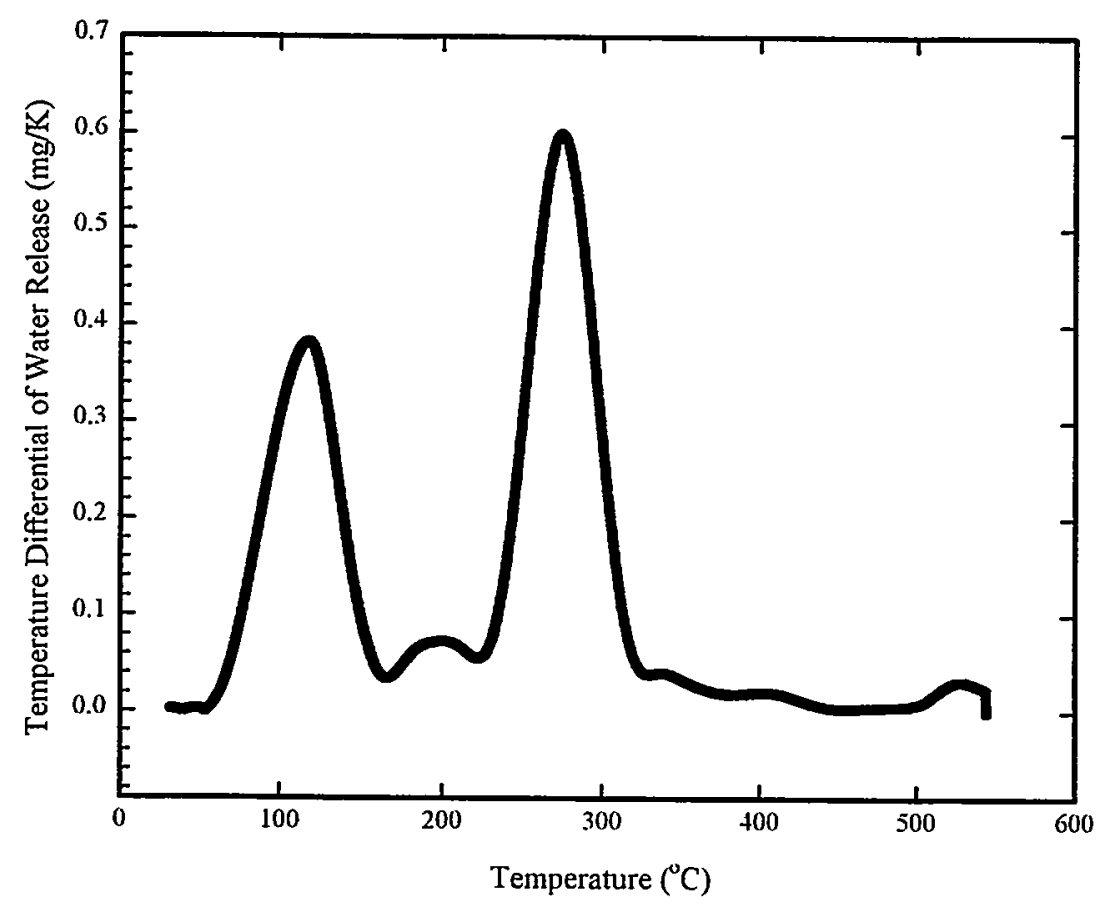

Figure A.6. Plot of the Temperature Differential of Water Release from SNF Coating Sample cs4 Derived from Figure 3.4a, TGA Run 64 


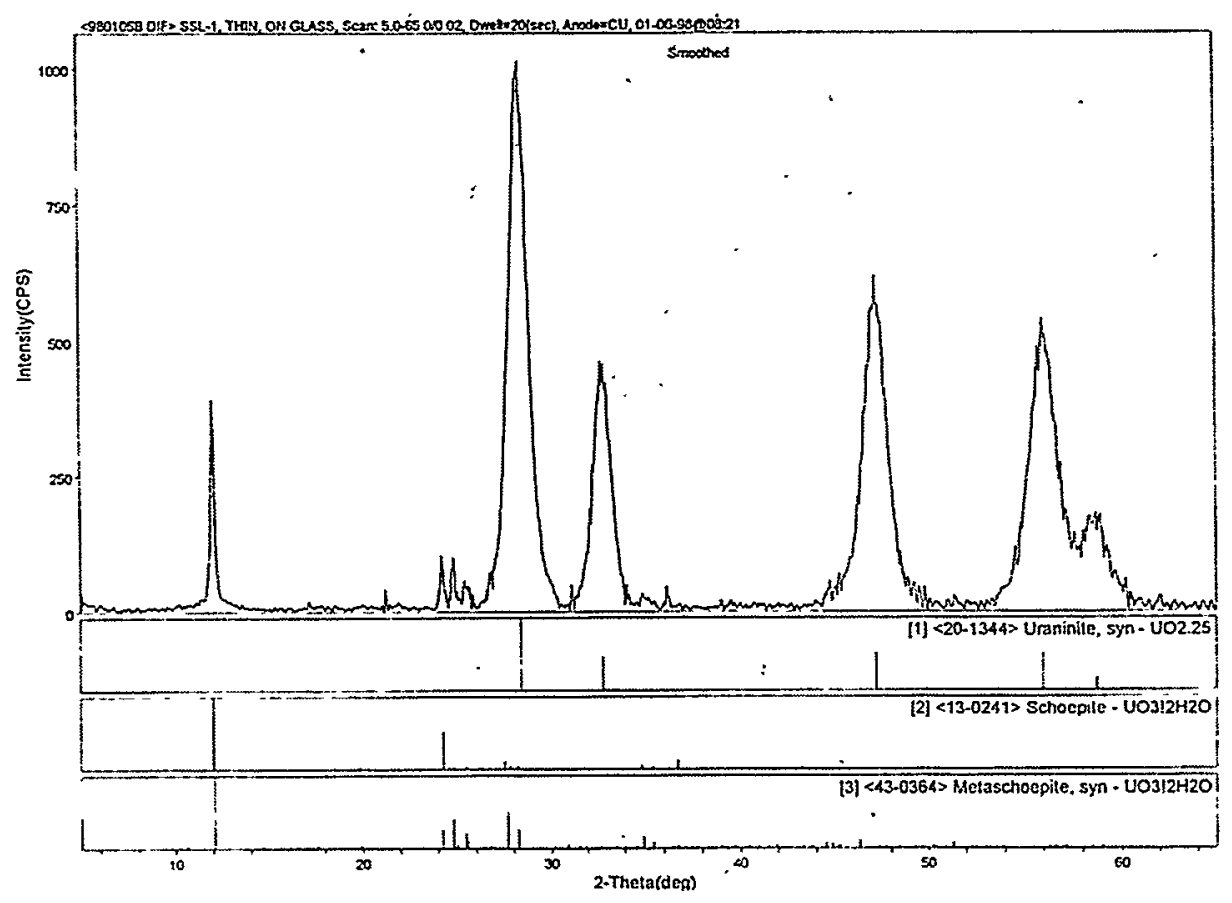

Figure A.7. Background Subtracted XRD Spectrum of SNF Internal Sludge ssl1. Stick figures of phases identified are included.

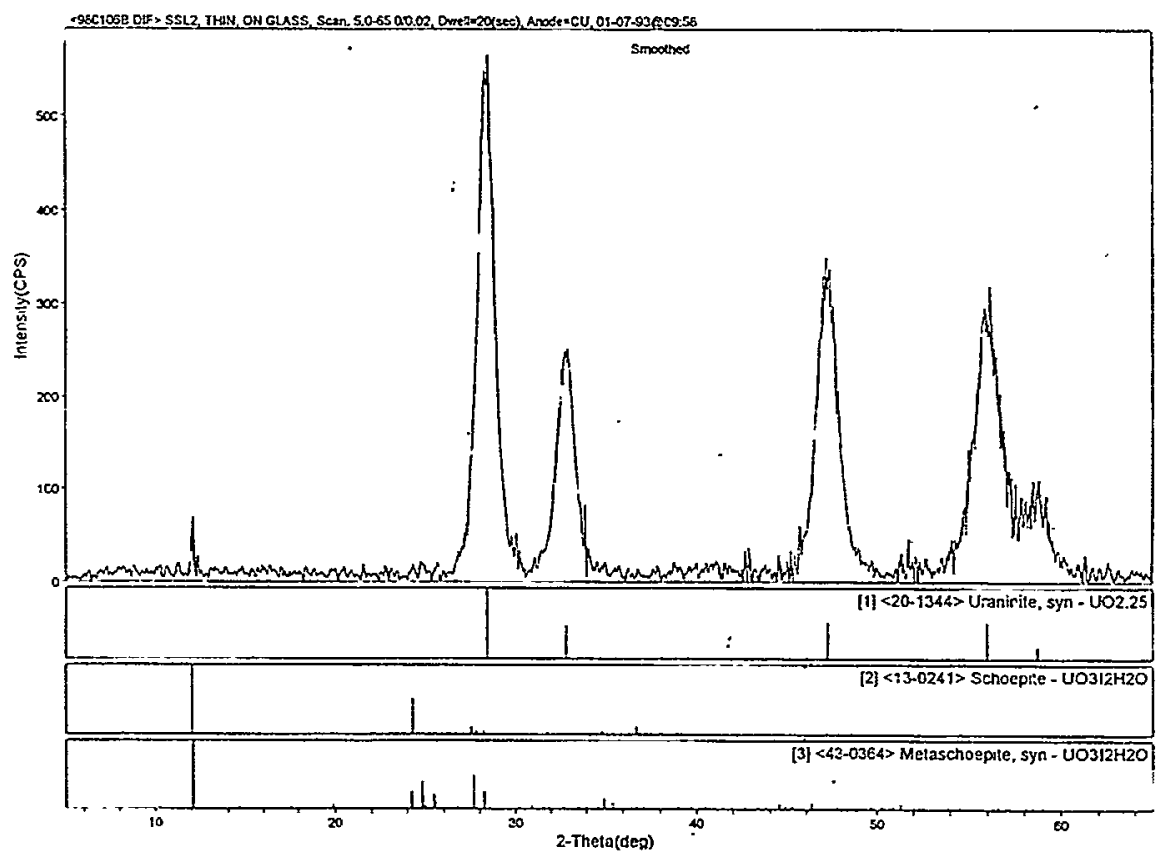

Figure A.8. Background Subtracted XRD Spectrum of SNF Internal Sludge ssl2. Stick figures of phases identified are included. 


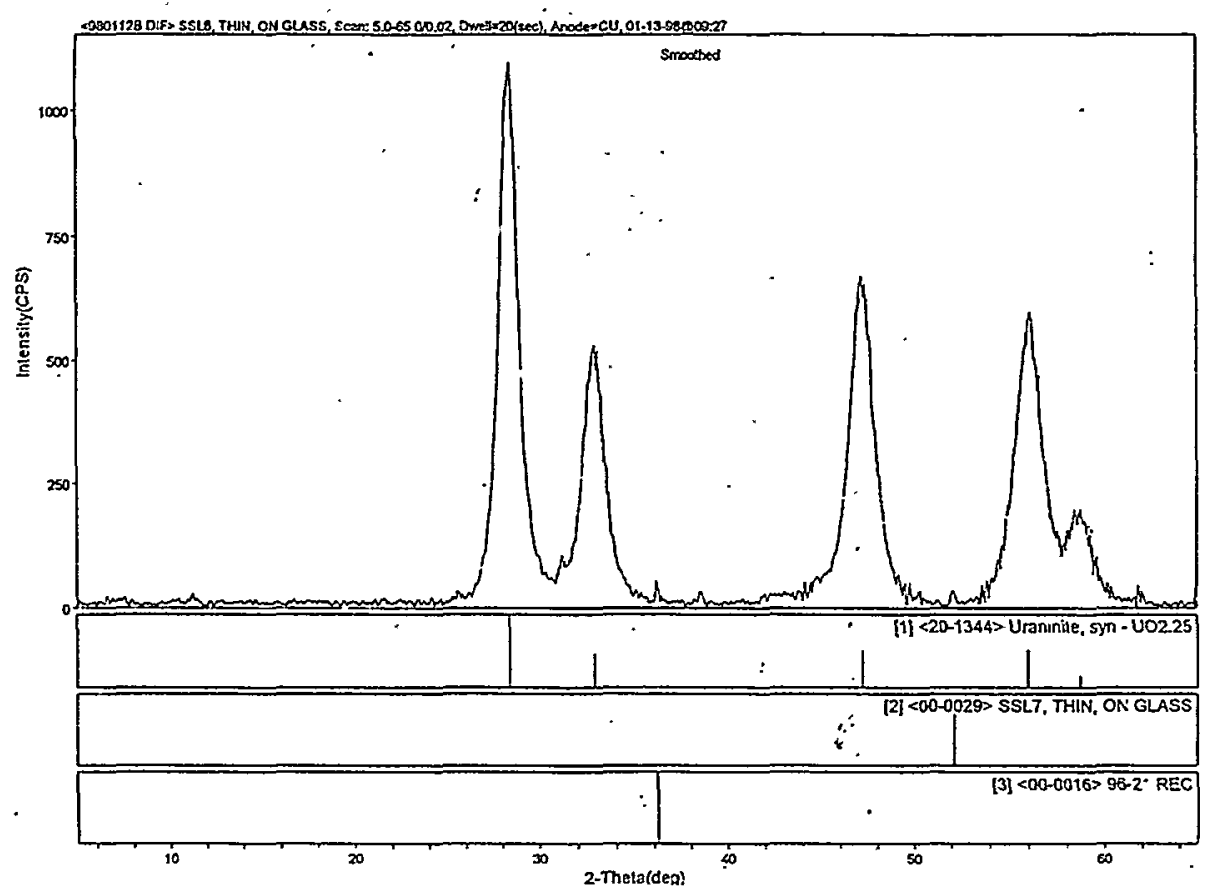

Figure A.9. Background Subtracted XRD Spectrum of SNF Internal Sludge ss13. Stick figures of phases identified are included.

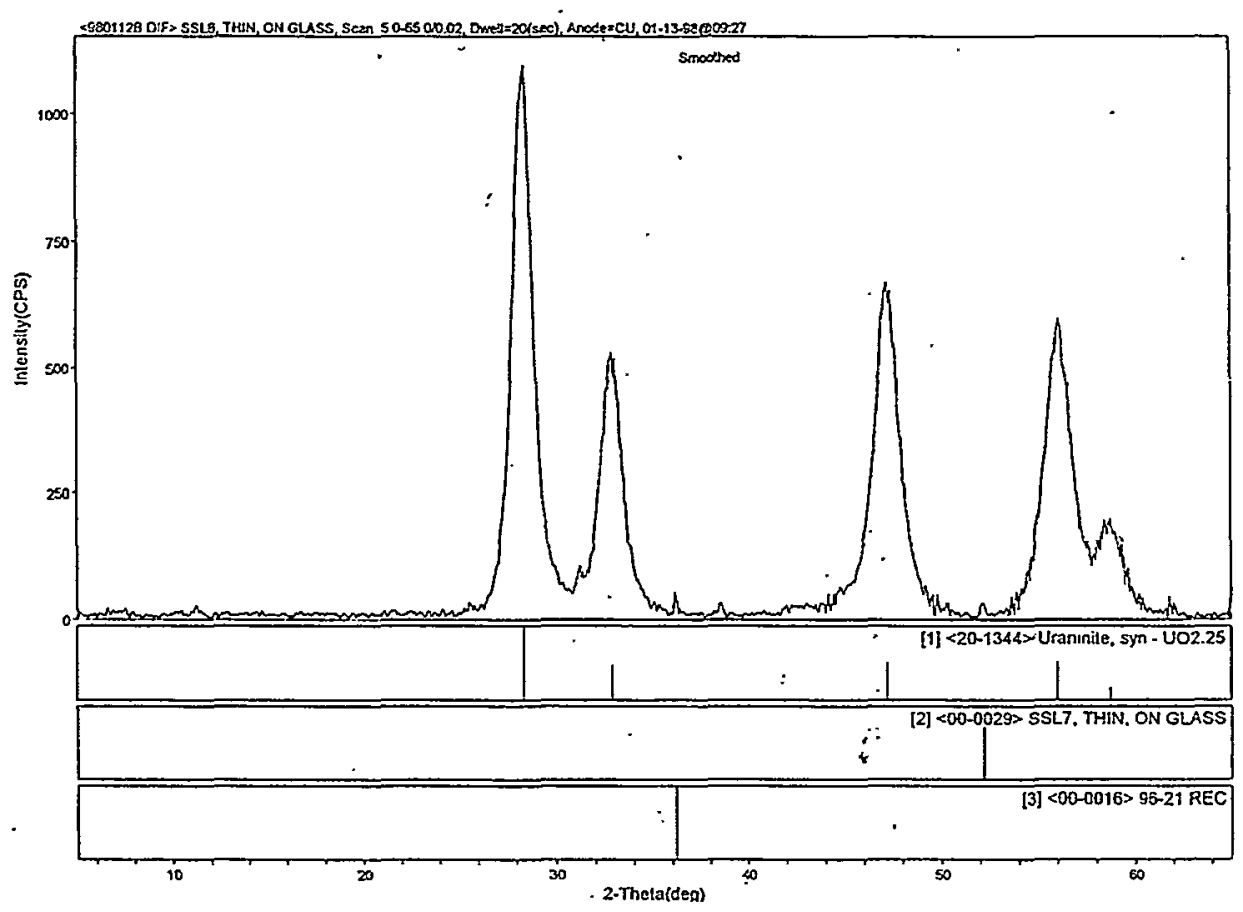

Figure A.10. Background Subtracted XRD Spectrum of SNF Internal Sludge ssl8. Stick figures of phases identified are included. 


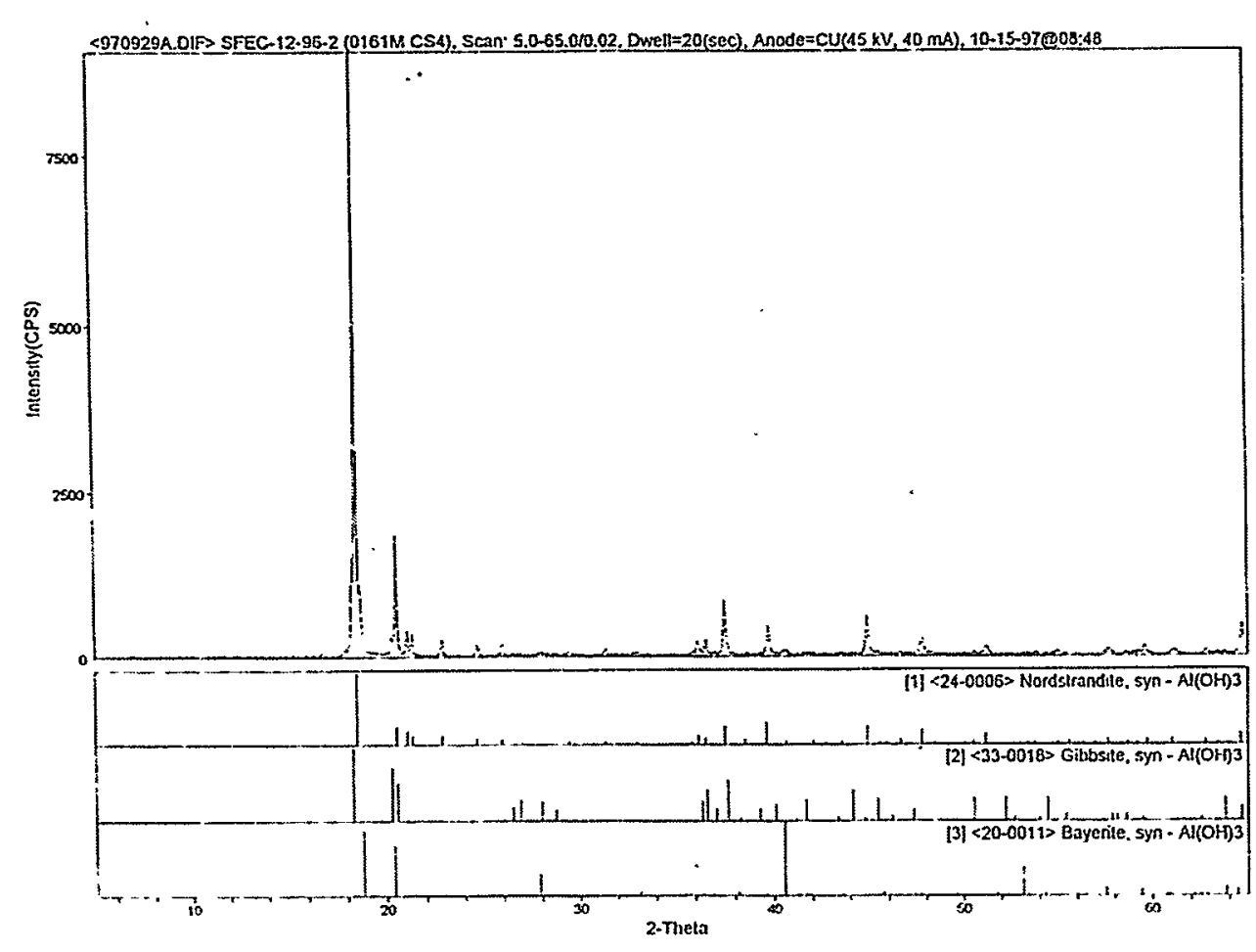

Figure A.11. Background Subtracted XRD Spectrum of SNF Surface Coating cs4. Stick figures of phases identified are included. 


\section{Distribution}

No. of

Copies

\section{OFFSITE}

C. L. Bendixsen

Idaho National Engineering and

Environmental Laboratory

P.O. Box 1625

Mailstop 3135

Idaho Falls, ID 83415

A. W. Conklin

Washington State Department of Health

Airdustrial Park

Building 5, Mailstop LE-13

Olympia, WA 98504-0095

M. A. Ebner

Idaho National Engineering and

Environmental Laboratory

P.O. Box 1625

Mailstop 3114

Idaho Falls, ID 83415

A. R. Griffith

U.S. Department of Energy, Headquarters 19901 Germantown Road (EH-34)

Germantown, MD 20874-1290

T. J. Hull

U.S. Department of Energy, Headquarters 19901 Germantown Road (EH-34)

Germantown, MD 20874-1290

M. R. Louthan

Savannah River Technology Center

Materials Technology Center

Aiken, SC 29808
No. of

Copies

T. E. Madey

Rutgers University

Bldg. 3865

136 Freylinghuysen Rd.

Piscataway, NJ 08854

B. K. Nelson

U.S. Department of Energy, Headquarters 19901 Germantown Road (EH-34)

Germantown, MD 20874-1290

R. G. Pahl, Jr.

Argonne National Laboratory

P.O. Box 2528

Idaho Falls, D 83403

R. S. Rosen

Lawrence Livermore National Laboratory 20201 Century Blvd. 1st Floor

Germantown, MD 20874

C. Silver

Washington State Department of Ecology

P.O. Box 47600

Olympia, WA $98504-7600$

T. A. Thornton

Yucca Mountain Project M\&O Contractor SUM1/423

1261 Town Center Drive

Las Vegas, NV 89134

Distr.1 
PNNL-11932

No. of

Copies

ONSITE

5 DOE Richland Operations Office

R. M. Hiegel

R3-81

R. G. Holt

P. G. Loscoe

C. R. Richins

J-S. Shuen

22 Spent Nuclear Fuel Project

R. B. Baker (3)

S. A. Chastain

T. Choho

D. R. Duncan

J. S. Frederickson

L. H. Goldmann

J. J. Irwin

B. J. Makenas

C. R. Miska

R. W. Rasmussen

J. A. Swenson

C. A. Thompson

D. J. Trimble (5)

D. J. Watson

J. H. Wicks, Jr.

SNF Project Files

R3-86

R3-86

R3-86

R3-86

X3-78

HO- 40

R3-86

X3-85

R3-11

X3-71

R3-86

X3-79

$\mathrm{X} 3-71$

R3-11
No. of

Copies

25 Pacific Northwest National Laboratory

J. Abrefah (5)

P7-27

D. L. Alexander (2)

P8-10

B. D. Hanson

P7-27

E. D. Jensen

P7-22

D. K. Kreid

K7-80

D. E. Knutson

P7-25

S. C. Marschman (3)

P7-27

B. M. Oliver

P7-22

R. P. Omberg

K7-80

J. K. Tarantino

K9-41

J. C. Wiborg

K7-74

Information Release Office (7)

K1-06 